\title{
Non-lipopeptide fungi-derived peptide antibiotics developed since 2000
}

\author{
Pengchao Zhao $\cdot$ Yun Xue 1 - Jinghua Li $\cdot$ Xin Li $\cdot$ Xiangyang Zu \\ Zhanqin Zhao $\cdot$ Chunshan Quan $\cdot$ Weina Gao $\cdot$ Shuxiao Feng
}

Received: 11 February 2019/Accepted: 22 April 2019/Published online: 24 April 2019

(C) Springer Nature B.V. 2019

\begin{abstract}
The 2,5-diketopiperazines (DKPs) are the smallest cyclopeptides and their basic structure includes a six-membered piperazine nucleus. Typical peptides lack a special functional group in the oligopeptide nucleus. Both are produced by at least 35 representative genera of fungi, and possess huge potential as pharmaceutical drugs and biocontrol agents. To date, only cyclosporin A has been developed into a commercial product. This review summarises 186 fungi-derived compounds reported since
\end{abstract}

P. Zhao $\cdot$ Y. Xue $(\varangle) \cdot$ J. Li $\cdot$ X. Zu $\cdot$ W. Gao

College of Medical Technology and Engineering, Henan

University of Science and Technology, Luoyang 471023,

China

e-mail: xueyun6688@163.com

X. Li

Life Science College, Yuncheng University,

Yuncheng 044000, China

Z. Zhao $(\bowtie)$

College of Animal Science and Technology, Henan

University of Science and Technology, Luoyang 471023,

China

e-mail: zhaozhanqin@126.com

C. Quan

Department of Life Science, Dalian Nationalities

University, Dalian 116600, China

S. Feng

College of Chemical Engineering and Pharmacy, Henan University of Science and Technology, Luoyang 471023, China
2000. Antibiotic (antibacterial, antifungal, synergistic antifungal, antiviral, antimycobacterial, antimalarial, antileishmanial, insecticidal, antitrypanosomal, nematicidal and antimicroalgal) activities are discussed for 107 of them, including 66 DKPs (14 epipolythiodioxopiperazines, 20 polysulphide bridgefree thiodiketopiperazines, and 32 sulphur-free prenylated indole DKPs), 15 highly $N$-methylated, and 26 non-highly $N$-methylated typical peptides. Structureactivity relationships, mechanisms of action, and research methods are covered in detail. Additionally, biosynthases of tardioxopiperazines and neoechinulins are highlighted. These compounds have attracted considerable interest within the pharmaceutical and agrochemical industries.

Keywords Antibiotic activity - DKP · Fungi · Mechanism of action - Structure-activity relationship . Typical peptide $\cdot$ Biosynthesis

\section{Introduction}

Fungi are well-known producers of bioactive secondary metabolites, especially short peptides of 30 residues or fewer, with interesting structures and antibiotic properties (Brase et al. 2009; Jia et al. 2015; Li et al. 2017; Wang et al. 2017a, b; Yu et al. 2012). Herein, we focus on fungal cyclodipeptides known as 2,5-diketopiperazines (DKPs), as well as typical 
peptides and their analogs, reported since 2000. Genera of fungi known to produce these compounds include Alternaria, Aspergillus, Asteromyces, Bionectra, Chaetomium, Clonostachys, Cordyceps, Cryptosporiopsis, Epicoccum, Eurotium, Eutypella, Fusarium, Gliocladium, Graphium, Lasiodiplodia, Metarhizium, Microascus, Mortierella, Myrothecium, Nectria, Omphalotus, Penicillium, Pestalotiopsis, Phoma, Phomopsis, Pseudallescheria, Pseudoxylaria, Schizophyllum, Simplicillium, Stagonospora, Stereum, Talaromyces, Trichoderma, Verticillium and Xylaria. Some of these molecules have been explored for potential applications (Wang et al. 2013a).

DKPs are the smallest cyclopeptides, and generated by the condensation of two amino acids (e.g. Try, Pro, Ala, His, Leu, Ile, Phe, Ser, Tyr, and Gly) (Wang et al. 2013a, 2017a). Their basic structure includes a sixmembered piperazine nucleus, and based on structural characteristics, they are classified as thiodiketopiperazines (TDKs) and sulphur-free DKPs. TDKs feature $S$-methyl (Me) groups and/or transannular polysulphide bridges (epipolythiodioxopiperazines, ETPs) (Guo et al. 2009; Li et al. 2013a; Meng et al. 2015a). Biosynthesis of DKPs can be achieved either by cyclodipeptide synthases (CDPSs) or non-ribosomal peptide synthases (NRPSs) that differ in the mode of activation of their amino acid substrates (Belin et al. 2012). To date, only six DKPs synthesized by CDPSs have been reported (albonoursin, mycocyclosin, pulcherriminic acid, bicyclomycin, drimentines, and nocazine XR334 and E) (Lautru et al. 2002; Belin et al. 2009; Cryle et al. 2010; Vior et al. 2018; Yao et al. 2018; Giessen et al. 2013; Zhang et al. 2013). To the best of our knowledge, the formation of fungiderived DKPs is catalysed by NRPSs. Structural modification of the DKP backbone is subsequently achieved by various tailoring enzymes including oxidoreductases, methyltransferases, prenyltransferases, cyclases and others (Wohlgemuth et al. 2018). Table 1 shows fungi-derived DKPs for which biosynthases have been identified (Saruwatari et al. 2014; Guo et al. 2013; Yin et al. 2009; Chankhamjon et al. 2014; Maiya et al. 2006, 2009; Mundt et al. 2012; Gerken and Walsh 2013; Oide et al. 2006; Wilhite et al. 2001; Wohlgemuth et al. 2017, 2018; Lazos et al. 2010; Lim et al. 2014; Gardiner and Howlett 2005; Sherkhane et al. 2017; Chu et al. 2010; García-Estrada et al. 2011; Ali et al.2013; Gardiner et al. 2004; Dopstadt et al. 2016; Wang et al. 2017c; Quezada et al.
2017). Peptides lacking special functional groups in the short oligopeptide nucleus are herein referred to as typical peptides. This review highlights their sources, biosynthesis, structural and sequence features, antibiotic activities, structure-activity relationships (SARs), mechanisms of action, and related research methods since 2000 in order to assist their future exploration and exploitation as novel pharmaceutical drugs or biocontrol agents.

\section{ETPs}

Research suggests that the crucial structural element of ETPs responsible for the observed biological properties is the polysulphide linkage ( $\mathrm{Li}$ et al. 2012a; Onodera et al. 2004). Based on differences in the amino acid composition of the ETP parent nucleus and further structural modification, 37 ETPs can be classified into 12 families: aspirochlorine, emestrins, epicorazines, gliotoxins, gliocladine $\mathrm{C}$, hyalodendrin, chetomins, verticillins, vertihemiptellides, aranotins, eutypellazine and gliovirins (Table 2 and Fig. 1).

The aspirochlorine tetrathiol analog tetrathioaspirochlorine from Aspergillus flavus 0G0S0151 is a potent antifungal agent against azole-resistant Candida albicans, with a $50 \%$ inhibitory concentration $\left(\mathrm{IC}_{50}\right)$ of $0.083 \mu \mathrm{M}$, stronger the three standard compounds amphotericin B, gliotoxin and griseofulvin, but less active than aspirochlorine (Klausmeyer et al. 2005). The 7-membered disulphide ring appears to play a key role in antifungal activity. Aspirochlorine antifungal activity is related to its ability to inhibit protein biosynthesis. Four $2^{\prime \prime}-O$-Me derivatives of emestrin and one $7^{\prime \prime}$-deoxy analog of emestrin named emestrin C (MPC1001), MPC1001C and emestrins D (MPC1001D)-F have been isolated. Emestrin C and MPC1001C, isolated from Cladorrhinum sp. KY4922 and Podospora australis TTI-0248, contain one disulphide bridge and two $O$-Me groups, and both show significant activity against Cryptococcus neoformans with minimum inhibitory concentrations (MICs) of 0.8 and $1.6 \mu \mathrm{g} \mathrm{ml}^{-1}$, respectively, close to that of amphotericin B (Li et al. 2016a; Onodera et al. 2004; Tsumagari et al. 2004). Nevertheless, the trisulphidebridged emestrin D (Cladorrhinum sp. KY4922 and $P$. australis TTI-0248), tetrasulphide-bridged emestrin E (Verticimonosporium ellipticus MF6822 and P. australis TTI-0248), and the disulphide bridge- single $O$ - 
Table 1 Biosynthases of fungi-derived DKPs

\begin{tabular}{|c|c|c|c|}
\hline DKPs & Sources & Biosynthases & Antibiotic activity \\
\hline (-)-Ditryptophenaline & Aspergillus & DtpABC & None \\
\hline Acetylaranotins & Aspergillus & AtaA, TC, J, IMG and FPLYH & Antiviral \\
\hline Acetylaszonalenin & Aspergillus and Neosartorya & Ana AT, PS and PT & None \\
\hline Aspirochlorine & Aspergillus & AclA-P and QSTUZ & Antifungal \\
\hline Brevianamide $\mathrm{F}$ & Aspergillus & FtmAB & Antibacterial \\
\hline Fumitremorgins & Aspergillus & FtmA-E, Ox1 and FtmPT3 & Antibacterial \\
\hline Verruculogen & Aspergillus & FtmA-E and Ox1 & Antifungal \\
\hline Tryprostatins & Aspergillus & FtmA-D & Antibacterial \\
\hline Chaetocin & Chaetomium & ChaABCEGIJKMNPTZ & None \\
\hline Coprogens & Cochliobolus & NPS6 & None \\
\hline Dimerumic acid & Trichoderma & Psy1 & None \\
\hline Echinulin & Aspergillus & EchPS, PT1 and PT2 & Antimycobacterial \\
\hline Tardioxopiperazines & Aspergillus & EchPS, PT1 and PT2 & Antibacterial \\
\hline Neoechinulins & Aspergillus & EchPS, PT1 and P450 & Antiviral \\
\hline Erythrochelin & Saccharopolyspora & ErcABCDEF & None \\
\hline Fumiquinazoline & Aspergillus & FmqABCDE & None \\
\hline Gliotoxin & Aspergillus & GliTFNAKGMCPJIZ & $\begin{array}{l}\text { Antimycobacterial, antifungal, } \\
\text { anti-trypanosomal }\end{array}$ \\
\hline Gliovirin & Trichoderma & Glv1-21 and 22 & Antifungal \\
\hline Notoamides/stephacidin & Aspergillus & NotA-E and F-R & None \\
\hline Roquefortine/Meleagrin & Penicillium & RoqARMONDT & None \\
\hline Sirodesmin PL & Leptosphaeria & SirA-E, G-J, M-P and QRSTZ & Antibacterial, antiviral \\
\hline Thioclapurine & Claviceps & TcpACDGJKNPTZ & None \\
\hline Verticillin & Clonostachys & VerATLMNICPKJGZB & Antibacterial, anti-trypanosomal \\
\hline Waspergillamide A & Aspergillus & PABA as the starter unit & None \\
\hline
\end{tabular}

Bold type denoting nonribosomal peptide synthase

None having no antibiotic activity, PABA $p$-aminobenzoic acid

Me-containing emestrin F (Armillaria tabescens JNBOZ344) display weaker anti-Cryptococcus activity (Herath et al. 2005, 2013; Li et al. 2016a). In addition, MPC1001 also exhibits good antimicrobial activity against Staphylococcus aureus, Bacillus subtilis, Enterococcus hirae and $C$. albicans, especially $B$. subtilis, for which the MIC is $2.1 \mu \mathrm{g} \mathrm{ml}^{-1}$ (Li et al. 2016a; Tsumagari et al. 2004). Emestrin $\mathrm{F}$ is also potently active against Mycobacterium intracellulare $\left(\mathrm{MIC}=1.25 \mu \mathrm{g} \mathrm{ml}^{-1} ; \mathrm{IC}_{50}=1.18 \mu \mathrm{g} \mathrm{ml}^{-1}\right.$ ) (Herath et al. 2013). This led to the conclusion that the $O-\mathrm{Me}$ groups and disulphide bridges are essential for potency. Mechanistic studies on the effects of emestrins led to the hypothesis that antimicrobial activity is due to inhibition of ATP synthesis in mitochondria, causing an uncoupling of oxidative phosphorylation and depression of respiration ( $\mathrm{Li}$ et al. 2016a; Herath et al. 2013). Brocazine G from Penicillium brocae MA-231 belongs to the epicorazine family and exhibits potent inhibitory activity against $S$. aureus ( $\mathrm{MIC}=0.25$ $\mu \mathrm{g} \mathrm{ml}^{-1}$ ), stronger than chloromycetin (Meng et al. 2016). Glionitrin A from Sphingomonas sp. KMK-001 and Aspergillus fumigatus KMC-901 belongs to the gliotoxin family and displays differential antibiotic activity against a range of microbes, especially Micrococcus leuteus and methicillin-resistant $S$. aureus $\left(\right.$ MRSA; MIC $=0.78 \mu \mathrm{g} \mathrm{ml}^{-1}$ ) (Park et al. 2009). Furthermore, gliotoxin addition can perturb the proteome and induce redox stress in fungi (Carberry et al. 2012; Pereira-Neves et al. 2016).

Gliocladine C-type GG1F1-1 and 2 from Phoma sp. GG1F1 were shown to be effective against 16 
Table 2 Epipolythiodioxopiperazines (ETPs) with antibiotic activities

\begin{tabular}{|c|c|c|}
\hline Class/name & Biosynthetic precursors & Antibiotic activity \\
\hline Aspirochlorine/tetrathioaspirochlorine & Cyclo-(Gly-Tyr) & Antifungal \\
\hline $\begin{array}{l}\text { Emestrin/emestrin C (MPC1001), MPC1001C and emestrins } \\
\text { D (MPC1001D)-F }\end{array}$ & Cyclo-(Phe-Phe) & $\begin{array}{l}\text { Antifungal, antibacterial, } \\
\text { antimycobacterial }\end{array}$ \\
\hline Epicorazine/brocazine G & Cyclo-(Phe-Phe) & Antibacterial \\
\hline Gliotoxin/glionitrin A & Cyclo-(Phe-Ser) & Antifungal, antibacterial \\
\hline Gliocladine C/GG1F1-1 and 2 & Cyclo-(Trp-Ser) & Antibacterial, antifungal \\
\hline Hyalodendrin/1-demethyl-hyalodendrin tetrasulfide & Cyclo-(Phe-Ser) & Antimalarial \\
\hline $\begin{array}{l}\text { Chetomin/chaetocochin } \mathrm{J} \\
\text { Chetoseminudin A }\end{array}$ & $\begin{array}{l}\text { Dimer: cyclo-(Trp-Ser)-cyclo- } \\
\text { (Trp-Ser) }\end{array}$ & Antibacterial \\
\hline \multicolumn{3}{|l|}{ 6-Formamide-chetomin } \\
\hline $\begin{array}{l}\text { Verticillin/gliocladines A and B } \\
\text { 11'-Deoxyverticillin A }\end{array}$ & $\begin{array}{l}\text { Dimer: cyclo-(Trp-Ala)-cyclo- } \\
\text { (Trp-Ala) }\end{array}$ & Antinematodal \\
\hline Sch52900 and Sch52901 & $\begin{array}{l}\text { Dimer: cyclo-(Trp-Abu/Thr)- } \\
\text { cyclo-(Trp-Ala) }\end{array}$ & \\
\hline Gliocladine C/gliocladines C-E & cyclo-(Trp-Ala) & Antinematodal \\
\hline Verticillin/Verticillin G & $\begin{array}{l}\text { Dimer: cyclo-(Trp-Ser)-cyclo- } \\
\text { (Trp-Gly) }\end{array}$ & Antibacterial \\
\hline Epicorazine/epicoccins $\mathrm{A}$ and $\mathrm{U}$ & Cyclo-(Phe-Phe) & Antibacterial \\
\hline Eutypellazine/eutypellazine Q & Cyclo-(Phe-Phe) & Antibacterial \\
\hline Gliocladine $\mathrm{C} /$ bionectins $\mathrm{A}$ and $\mathrm{B}$ & Cyclo-(Trp-Gly/Thr) & Antibacterial \\
\hline Gliovirin/outovirin $\mathrm{C}$ & Cyclo-(Phe-Tyr) & Antifungal \\
\hline Vertihemiptellide/vertihemiptellides A and B & $\begin{array}{l}\text { Dimer: cyclo-(Phe-Ser)-cyclo- } \\
\text { (Phe-Ser) }\end{array}$ & Antimycobacterial \\
\hline Gliovirin/pretrichodermamide A & Cyclo-(Phe-Tyr) & Antimycobacterial \\
\hline Gliovirin/adametizines $\mathrm{A}$ and $\mathrm{B}$ & Cyclo-(Phe-Tyr) & Antibacterial, antifungal \\
\hline Epicorazine/epicorazine C & Cyclo-(Phe-Phe) & $\begin{array}{l}\text { Antimycobacterial, } \\
\text { antibacterial, antifungal }\end{array}$ \\
\hline Aranotin/graphiumins A and I & Cyclo-(Phe-Phe) & Anti-virulence \\
\hline
\end{tabular}

Classes are indicated in bold

$A b u$ aminobutyric acid

pathogens, especially S. aureus, MRSA, Bacillus cereus, Staphylococcus warneri and Streptococcus pyogenes, with $\mathrm{IC}_{50}$ values $<10 \mu \mathrm{M}$ (Arora et al. 2016). In addition, GG1F1-1 inhibits Klebsiella pneumonia $\left(\mathrm{IC}_{50}=4.5 \mu \mathrm{M}\right)$. Interestingly, they also strongly inhibit biofilm formation in $S$. aureus and $S$. pyogenes, and were found to act synergistically with streptomycin while exerting varying effects in combination with ciprofloxacin and ampicillin. 1-demethyl-hyalodendrin tetrasulphide from Verticillium hemipterigenum BCC 1449 belongs to the hyalodendrin family (Nilanonta et al. 2003). This compound significantly inhibits the proliferation of multi-drug resistant $P$. falciparum $\left(\mathrm{IC}_{50-}\right.$ $=2.5 \mu \mathrm{g} \mathrm{ml}^{-1}$ ), but its bisdimethylthio ether is inactive, indicating that the tetrasulphide bridge is crucial for achieving high antimalarial activity. Three ETP dimeric members of the chetomin family have been identified (chaetocochin J, chetoseminudin A and 6-formamide-chetomin). Chetoseminudin A from Chaetomium seminudum 72-S-204-1 and Chaetomium globosum CIB-G3604 contains one disulphide and one trisulphide bridge (Fujimoto et al. 2004; Xu et al. 2015), and displays strong activity against $B$. subtilis $\left(\mathrm{MIC}=0.78 \mu \mathrm{g} \mathrm{ml}^{-1}\right.$ ), more active than chaetocochin $\mathrm{J}$ containing only one tetrasulphide bridge (Xu et al. 2015). These results suggest that the number of sulphur bridges is important for maintaining high anti-Bacillus activity. 6-formamide-chetomin from Chaetomium sp. M336 has strong antibacterial activity 
Fig. 1 Structure of partial ETPs. a Aspirochlorine/ tetrathioaspirochlorine. b Emestrin $\mathrm{C}\left(\mathrm{n}_{1}=2\right.$, $\left.\mathrm{R}_{1}=\mathrm{OH}, \mathrm{R}_{2}=\mathrm{CH}_{3}\right)$; $\operatorname{MPC} 1001 \mathrm{C}\left(\mathrm{n}_{1}=2\right.$, $\left.\mathrm{R}_{1}=\mathrm{H}, \mathrm{R}_{2}=\mathrm{CH}_{3}\right)$; emestrin $\mathrm{D}\left(\mathrm{n}_{1}=3\right.$, $\left.\mathrm{R}_{1}=\mathrm{OH}, \mathrm{R}_{2}=\mathrm{CH}_{3}\right) ; \mathrm{E}$ $\left(\mathrm{n}_{1}=4, \mathrm{R}_{1}=\mathrm{OH}\right.$,

$\left.\mathrm{R}_{2}=\mathrm{CH}_{3}\right) ; \mathrm{F}\left(\mathrm{n}_{1}=2\right.$,

$\left.\mathrm{R}_{1}=\mathrm{H}, \mathrm{R}_{2}=\mathrm{H}\right)$.

c Epicorazine/brocazine $\mathrm{G}$.

d Gliotoxin/glionitrin A. e Gliocladine C/GG1F1-1 $\left(\mathrm{n}_{2}=2\right)$; GG1F1-2 ( $\left.\mathrm{n}_{2}=3\right)$. f Hyalodendrin/1-demethylhyalodendrin tetrasulphide. g Chetomins/ chetoseminudin $\mathrm{A}\left(\mathrm{R}_{3}=\mathrm{H}\right.$, $\mathrm{n}_{3}=3$ ); 6-formamidechetomin $\left(\mathrm{R}_{3}=\mathrm{CHO}\right.$, $\left.\mathrm{n}_{3}=2\right)$. h Chaetocochin $\mathrm{J}$ (Klausmeyer et al. 2005; Li et al. 2016a; Herath et al. 2013; Meng et al. 2016; Park et al. 2009; Arora et al. 2016; Nilanonta et al. 2003; $\mathrm{Xu}$ et al. 2015; Yu et al. 2018) (a)<smiles>CON1C(=O)C2SSSS[C@@H]3NC(=O)[C@]21Oc1cc(O)c(Cl)cc13</smiles>

(b)

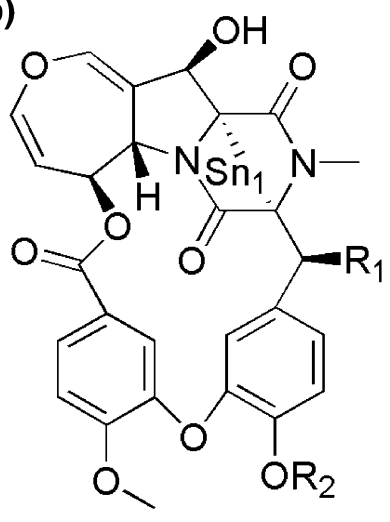

(c)

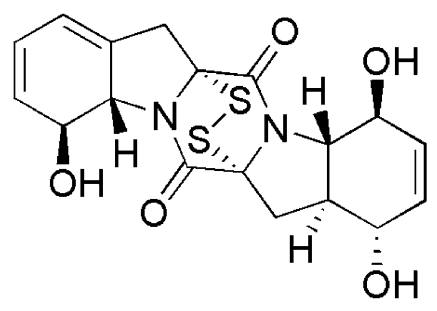<smiles>CN1C(=O)C23Cc4ccc([N+](=O)[O-])cc4N2C(=O)[C@]1(CO)SSS3</smiles>

(e)

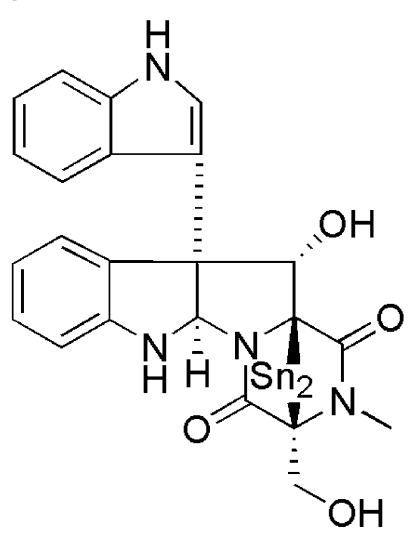

(f)<smiles>CN1C(=O)[C@H](CO)NC(=O)[C@@]1(C)Cc1ccccc1</smiles>

(g)

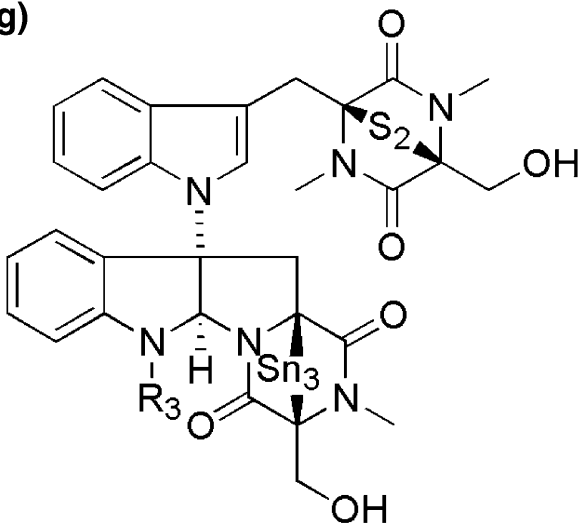

(h)<smiles>CN1C(=O)C2=C[C@]3(n4cc(C[C@]56SS[C@](CO)(C(=O)N5C)N(C)C6=O)c5ccccc54)c4ccccc4NC3N2C(=O)[C@@H]1CO</smiles> 
against Escherichia coli, S. aureus, Salmonella typhimurium and E. faecalis (MICs $=0.78 \mu \mathrm{g} \mathrm{ml}^{-1}$ ) (Yu et al. 2018). Antibiotic activities of other ETPs are listed in Table 2 (Chunyu et al. 2017; Dong et al. 2005; Fukuda et al. 2015a, b; Isaka et al. 2005; Kajula et al. 2016; Kleinwächter et al. 2001; Liu et al. 2015a; Niu et al. 2017a; Park et al. 2009; Seephonkai et al. 2006; Zhang et al. 2007a; Zheng et al. 2006, 2007a).

\section{Polysulphide bridge-free TDKs}

Since 2000, 40 polysulphide bridge-free TDKs have been reported (Table 3 and Fig. 2). Chetoseminudin B from C. seminudum 72-S-204-1 and A. fumigatus 030402dZa possesses one dethio-dimethylthio-dioxopiperazine moiety (Fujimoto et al. 2004; Watts et al. 2010). Compared with the nM activity exhibited by gliotoxin, verticillin $\mathrm{B}$ and chaetocin, the $\mu \mathrm{M}$ activity of chetoseminudin B confirms the role of the disulphide bridge in the remarkable potency against Trypanosoma brucei. Epicoccins $\mathrm{G}$ and $\mathrm{H}$ from $E$. nigrum XZC04-CS-302 show differential inhibitory effects on HIV-1 replication in C8166 cells, indicating that two hydroxyl substitutions at C-7 and C-7' significantly increase activity (Guo et al. 2009). Anti-HIV bioassays indicated that eutypellazines A-
L from Eutypella sp. MCCC 3A00281 exhibit inhibitory effects against pNL4.3.Env-.Luc co-transfected 293T cells (HIV-1 model cells) with low cytotoxicity, and the $\mathrm{E}$ form exerts the highest activity $\left(\mathrm{IC}_{50}=3.2 \mu \mathrm{M}\right)(\mathrm{Niu}$ et al. 2017b). A preliminary SAR study revealed that analogs with an $S$-Me group at $\mathrm{C}-2^{\prime}$ (D and $\mathrm{E}$ ) are more active than those with one monosulfide bridge between $\mathrm{C}-2^{\prime}$ and $\mathrm{C}-7^{\prime}$ (A-C and $\mathrm{F}-\mathrm{H})$. Comparison of the inhibitory effects of $\mathrm{D}$ and $\mathrm{E}$ revealed a double bond at C- $6^{\prime} / \mathrm{C}-7^{\prime}$ in $\mathrm{E}$ that enhances activity. Regarding eutypellazines I-M, analogs with two $S$-Me groups at C-2 and C-2' (J) exert a stronger effect than those with $O$-Me/hydroxyl substitution $(\mathrm{K}-$ $\mathrm{M})$ or with a double bond at C-2'/C-3' (I). In addition, both eutypellazine $\mathrm{J}$ and epicoccin A can reactivate latent HIV-1 transcription at a dose of $80 \mu \mathrm{M}$ in a dose-dependent manner.

Lasiodipline E from Lasiodiplodia pseudotheobromae $\mathrm{F} 2$ possesses two $S$-Me and one $N$-Me groups, and this compound exerted antibacterial activity against five clinical strains, of which the most susceptible were Streptococcus sp., Bacteroides vulgates and Peptostreptococcus sp. (MICs $=0.12 \mu \mathrm{g} \mathrm{ml}^{-1}$ ), superior to tinidazole (Wei et al. 2014). Lasiodipline $\mathrm{E}$ is also active against Veillonella parvula (MIC $=0.25 \mu \mathrm{g} \mathrm{ml}^{-1}$ ) and Actinomyces israelii. Penicibrocazines B-E from $P$. brocae MA-231

Table 3 Polysulphide bridge-free thiodiketopiperazines (TDKs) with antibiotic activities

\begin{tabular}{lll}
\hline Name & Biosynthetic precursors & Antibiotic activity \\
\hline Chetoseminudin B & Cyclo-(Trp-Ser) & Anti-trypanosomal \\
Epicoccins G and H & Cyclo-(Phe-Phe) & Antiviral \\
Eutypellazines A-L & Cyclo-(Phe-Phe) & Antiviral \\
Lasiodipline E & Cyclo-(Trp-Ala) & Antibacterial \\
Penicibrocazines B-E & Cyclo-(Phe-Phe) & Antibacterial, antifungal \\
Dehydroxybisdethiobis(methylthio)gliotoxin & Cyclo-(Phe-Ala) & Antibacterial \\
Eutypellazines N-P, R and S & Cyclo-(Phe-Phe) & Antibacterial \\
Glioperazine B & Cyclo-(Trp-Thr) & Antibacterial \\
Spirobrocazine A & Cyclo-(Phe-Phe) & Antibacterial \\
Haematocin & Cyclo-(Phe-Phe) & Antifungal \\
Peniciadametizines A and B & Cyclo-(Phe-Phe) & Antifungal \\
Alternarosin A & Cyclo-(Phe-Phe) & Antibacterial, antifungal \\
Bis- $N$-norgliovictin & Cyclo-(Phe-Ser) & Antibacterial, antifungal \\
Bisdethiobis(methylsulfanyl)apoaranotin & Cyclo-(Phe-Phe) & Antimycobacterial \\
Bisdethiodi(methylthio)-1-demethylhyalodendrin & Cyclo-(Phe-Ser) & Antimycobacterial \\
Graphiumins D, E, G, H and J & Cyclo-(Phe-Phe) & Anti-virulence \\
\hline
\end{tabular}


(a)<smiles>[R1][C@@]1(SC)C(=O)N[C@](Cc2c[nH]c3ccccc23)(SC)C(=O)N1C</smiles>

(b)

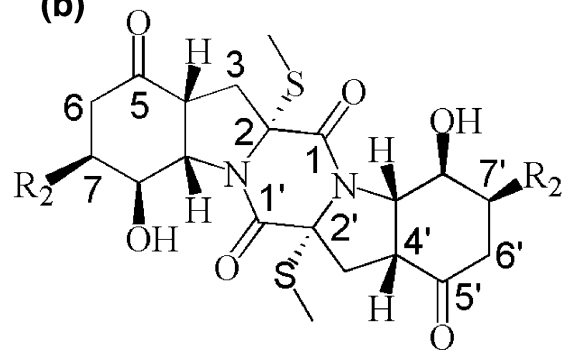

(c)

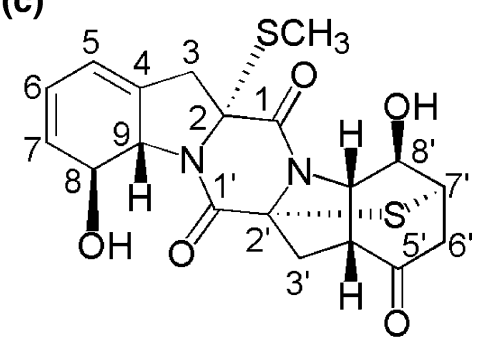

(d)

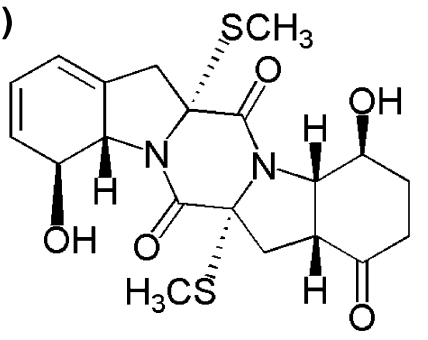

(e)<smiles>CS[C@@H]1C[C@H]2C(=O)C=C[C@H](O)[C@H]2N2C(=O)[C@]3(C)CC4=CC=C[C@H](O)[C@H]4N3C(=O)[C@H]12</smiles>

(f)

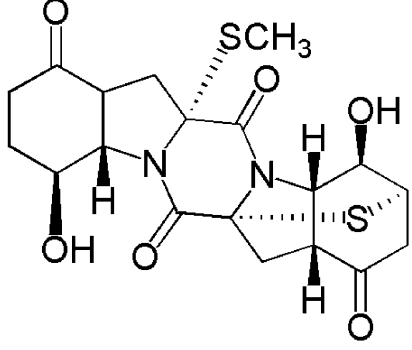

(g)<smiles>C[C@]1(Cc2ccccc2O)NC(=O)[C@H](C=C2[CH]C=[C+]C=C2)NC1=O</smiles>

(h)<smiles>CS[C@@H](C)[C@@]1(Cc2ccccc2)NC(=O)[C@](C)(Cc2ccccc2O)NC1=O</smiles>

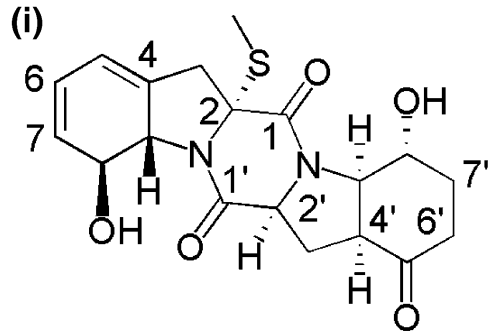

(j) $\mathrm{OH}$<smiles>CS[C@]12C[C@H]3[C@@H](O)C=C[C@H](O)[C@H]3N1C(=O)[C@@]1(SC)C[C@H]3[C@@H](C)C=C[C@H](O)[C@@H]3N1C2=O</smiles>

(k)<smiles>CS[C@]12C[C@H]3C(=O)CC[C@@H](O)[C@H]3N1C(=O)[C@]1(SC)C[C@H]3C(=O)CC[C@H](O)[C@@H]3N1C2=O</smiles>

(I)<smiles>CS[C@]12C[C@H]3C(=O)CC[C@@H](O)[C@H]3N1C(=O)[C@@]1(SC)C[C@H]3C(=O)CC[C@@H](O)[C@H]3N1C2=O</smiles>

Fig. 2 Structure of partial polysulphide bridge-free TDKs. a Chetoseminudin $\mathrm{B}\left(\mathrm{R}_{1}=\mathrm{CH}_{2} \mathrm{OH}\right)$ and lasiodipline $\mathrm{E}$ $\left(\mathrm{R}_{1}=\mathrm{CH}_{3}\right)$. b Epicoccins $\mathrm{G}\left(\mathrm{R}_{2}=\mathrm{H}\right)$ and $\mathrm{H}\left(\mathrm{R}_{2}=\mathrm{OH}\right)$. c-

possess a 6-5-6-5-6 DKP skeleton and one or two $S$ Me groups at C-2/C-2' (Meng et al. 2015a). They exhibit selective antimicrobial activity against some of the tested strains; B-D show activity against $S$. aureus, with $\mathrm{C}$ the most potent $\left(\mathrm{MIC}=0.25 \mu \mathrm{g} \mathrm{ml}^{-1}\right.$ ), more active than chloromycetin; $\mathrm{C}$ also displays potent activity against Micrococcus luteus $\left(\mathrm{MIC}=0.25 \mu \mathrm{g} \mathrm{ml}^{-1}\right.$ compared with $2.0 \mu \mathrm{g} \mathrm{ml}^{-1}$ for chloromycetin); B, D and E exhibit activity against Gaeumannomyces graminis, especially $\mathrm{B}$ and $\mathrm{E}$ $\left(\mathrm{MICs}=0.25 \mu \mathrm{g} \mathrm{ml}^{-1}\right.$ compared with $16.0 \mu \mathrm{g} \mathrm{ml}^{-1}$ h Eutypellazines A, D-F, I and J. i-l Penicibrocazines B-E (Fujimoto et al. 2004; Wei et al. 2014; Guo et al. 2009; Niu et al. 2017b; Meng et al. 2015a)

for amphotericin B). These findings indicate that the double bonds at C-6/C-7 and C-6 $/ \mathrm{C}-7^{\prime}$ increase activity against $S$. aureus. In addition, more $S$-Me groups likely strengthen activity against $G$. graminis, and keto groups at $\mathrm{C}-5 / 5^{\prime}$ also enhance activity. Antibiotic activities of other polysulphide bridge-free TDKs are listed in Table 3 (Fukuda et al. 2015a, b; Gulder et al. 2012; Haritakun et al. 2012; Isaka et al. 2005; Li et al. 2006; Liu et al. 2015b; Meng et al. 2016; Niu et al. 2017a; Suzuki et al. 2000; Wang et al. 2009; Zheng et al. 2007b). 


\section{Sulphur-free DKPs}

Prenylated indole DKPs, the largest family of sulphurfree compounds, are mainly produced by Aspergillus and Penicillium. They have three hallmark features; common biogenesis from tryptophan, one to three isopentenyl units, and a DKP nucleus (Chang et al. 2016). To date, 60 sulphur-free DKPs, including 42 prenylated indoles, have been identified (Tables 4 and 5; Fig. 3).

Dimeric brevianamide $\mathrm{S}$ dimerised via a C-8-C-8' bond was isolated together with monomeric brevianamides $\mathrm{T}-\mathrm{V}$ from Aspergillus versicolor MF030, and all four exhibit selective activity against Bacille Calmette-Guerin (BCG), although activity for $\mathrm{S}$ was modest, indicating that the dimeric structure is important for enhancing antimycobacterial activity (Song et al. 2012). Diketopiperazine M-3 from the fungus M-3 strongly inhibits the mycelial growth of $P$. oryzae by inducing curling and swelling (MIC $=0.36$ $\mu \mathrm{M}$ ), and it triggers morphological changes in the mycelia via similar mechanisms to those of the commercial antifungicidal agent rhizoxin (Byun et al. 2003). Therefore, M-3 may prove to be a valuable anti-fungicidal agent against rice blast disease. Neoechinulin B from Aspergillus amstelodami and E. rubrum $\mathrm{F} 33$ are structural analogs of rubrumlines A-O from E. rubrum F33 (Chen et al. 2015). These compounds reduce cytopathic effects on influenza A/WSN/33 virus, especially neoechinulin B which is the most potent $\left(\mathrm{IC}_{50}=27.4 \mu \mathrm{M}\right)$, and they are also effective against two clinical influenza virus isolates (oseltamivir-resistant LN/1109 and amantadine- and ribavirin-resistant HN/1222 strains). Analysis of the mechanism of action indicated binding to hemagglutinin in the influenza envelope, disrupting its interaction with the sialic acid receptor and the attachment of viruses to host cells. Further SAR analysis revealed that the $\Delta^{8,9}$ bond and a $\Delta^{12,15}$ unit of rubrumline $\mathrm{D}$ significantly enhance antiviral activity. Rubrumline $\mathrm{N}$, which has an $O$-Me group at $\mathrm{C}-8$, has a stronger antiviral effect than rubrumline $\mathrm{M}$ in which a hydroxyl group is substituted at C-8. In addition, based on neoechinulin $\mathrm{B}$, an isopentenyl or oxygenated isopentenyl group attached to the indole ring in the scaffold of indole-bearing DKPs appears to be unfavourable for antiviral activity. Furthermore, neoechinulin B biosynthase consists of one NRPS (EchPS), a prenyltransferase (EchPT1) and a cytochrome P450 enzyme (EchP450) that catalyses dehydrogenation forming two olefin bonds (Table 1). Okaramine Q from Penicillium simplicissimum ATCC 90288 is a demethoxy derivative of okaramine B possessing an octacyclic ring system, including a fourmembered azetidine ring and an eight-membered azocine ring (Shiono et al. 2000). This compound shows insecticidal activity against silkworms, albeit less than okaramine $\mathrm{B}$, suggesting that the $O$-Me group at $\mathrm{C}-3$ enhances this activity. Additionally, an azocine ring moiety with an appropriate conformation and an $\mathrm{N}$-aliphatic group attached to the indole are important for activity. Furthermore, the molecular target in Bombyx mori is the glutamate-gated chloride channel, also the molecular target of ivermectin (Furutani et al. 2014; Kato et al. 2018). However, unlike ivermectin, this agent exerts minimal toxicity toward human glycine or $\gamma$-aminobutyric acid receptors, even at high concentrations. Speramide A from freshwater-derived A. ochraceus KM007 possesses an aza-spiro structure, and has potent activity against Pseudomonas aeruginosa (MIC $=0.8 \mu \mathrm{M})$ (Chang et al. 2016).

Tardioxopiperazine A from Microascus tardifaciens IFM4564 and E. cristatum EN-220 displays potent inhibitory activity against $S$. aureus $\left(\mathrm{MIC}=8 \mu \mathrm{g} \mathrm{ml}^{-1}\right)$, more than its analogs cristatumin A and isoechinulin A (Du et al. 2012; Fujimoto et al. 1999). The structures only differ at C-8/C-9, indicating that the single bond between $\mathrm{C}-8 / \mathrm{C}-9$ is essential to antibacterial activity. Like neoechinulin $\mathrm{B}$, tardioxopiperazine A biosynthase contains one NRPS (EchPS) and two prenyltransferases (EchPT1 and PT2; Table 1). The Trp-derived alkaloid cyclo- $N$-Meanthranilic acid- $N$-hydroxy-2-one-3-isopentenyl-Trp from Mediterranean Aspergillus sp. strongly inhibits $V$. harveyi, $V$. natriegens, $V$. proteolyticus and $V$. carchariae (MICs $=0.1-1 \mu \mathrm{g} \mathrm{ml}^{-1}$ ) (Zhou et al. 2014). Waikialoids A and B from Aspergillus sp. JQ693975 are asymmetric dimeric DKPs, and both are complex prenylated indole alkaloids, but only the B form has a nitrone at $\mathrm{N}-39$ and a hydroxyl group at C-50 (Wang et al. 2012). These compounds display dose-dependent activity against $C$. albicans in biofilm inhibition assays, and the A form is especially active $\left(\mathrm{IC}_{50}=1.4 \mu \mathrm{M}\right)$. Both inhibit cell adherence, hyphal development, and biofilm assembly during the early stages of surface colonisation. 12 $\beta$-hydroxy-13 $\alpha$ methoxyverruculogen TR-2 from A. fumigatus LN-4 is a methylated derivative of verruculogen TR-2 and 
Table 4 Sulphur-free prenylated indole diketopiperazines (DKPs) with antibiotic activities

\begin{tabular}{|c|c|c|}
\hline Name & Biosynthetic precursors & Antibiotic activity \\
\hline Brevianamide $\mathrm{S}$ & $\begin{array}{l}\text { Dimer: cyclo-(Pro-Trp)-cyclo- } \\
\text { (Pro-Trp) }\end{array}$ & Antimycobacterial \\
\hline Brevianamides $\mathrm{T}-\mathrm{V}$ & Cyclo-(Pro-Trp) & \\
\hline Diketopiperazine M-3 & Cyclo-(Trp-Val) & Antifungal \\
\hline Neoechinulin B & Cyclo-(Ser-Trp) & Antiviral \\
\hline \multicolumn{3}{|l|}{ Rubrumlines A-O } \\
\hline Okaramine Q & Cyclo-(Trp-Trp) & Insecticidal \\
\hline Speramide A & Cyclo-(Pro-Trp) & Antibacterial \\
\hline Tardioxopiperazine A & Cyclo-(Ala-Trp) & Antibacterial \\
\hline Trp derived alkaloid & Cyclo- $\left({ }^{1}\right.$ ATA-Trp $)$ & Antibacterial \\
\hline Waikialoids A and B & $\begin{array}{l}\text { Dimer: cyclo-(Pro-Trp)-cyclo- } \\
\text { (Pro-Trp) }\end{array}$ & Anti-biofilm \\
\hline 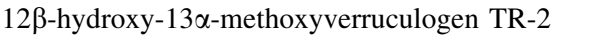 & Cyclo-(Pro-Trp) & Antifungal \\
\hline 12,13-dihydroxyfumitremorgin $\mathrm{C}$ & Cyclo-(Pro-Trp) & $\begin{array}{l}\text { Antibacterial, antimycobacterial, anti- } \\
\text { trypanosomal }\end{array}$ \\
\hline 6-Methoxyspirotryprostatin B & Cyclo-(Pro-Trp) & Anti-trypanosomal \\
\hline $\begin{array}{l}\text { BOC derivatives of fumitremorgin } \mathrm{C} \text { and } \\
\text { tryprostatin } \mathrm{B}\end{array}$ & Cyclo-(Pro-Trp) & Antibacterial \\
\hline Avrainvillamide (CJ-17,665) & Cyclo-(Pro-Trp) & Antibacterial \\
\hline Cyclo-(glycyl-L-tyrosyl)-4,4-dimethylallyl ether & Cyclo-(Gly-Tyr) & Antibacterial \\
\hline Cristatumin A & Cyclo-(Ser-Trp) & Antibacterial \\
\hline Dihydroxyisoechinulin A & Cyclo-(Ala-Trp) & Antibacterial \\
\hline Novoamauromine & Cyclo-(Trp-Trp) & Antifungal \\
\hline Ent-cycloechinulin & Cyclo-(Trp-Ala) & \\
\hline Piscarinines $\mathrm{A}$ and $\mathrm{B}$ & Cyclo-(Pro-Trp) & Antibacterial, antifungal \\
\hline Talathermophilins A and B & Cyclo-(Gly/Ala-Trp) & Nematicidal \\
\hline
\end{tabular}

$A T A$ anthranilic acid, BOC tert-butyloxycarbonyl

12ß-hydroxyverruculogen TR-2 (Li et al. 2012b). It displays varying degrees of activity against $B$. cinerea, Alternaria solani, Alternaria alternata, Colletotrichum gloeosporioides, Gibberella saubinettii, Fusarium solani and F. oxysporum, especially the former five strains ( $\mathrm{MICs}=6.25 \mu \mathrm{g} \mathrm{ml}^{-1}$ ). It is more active than verruculogen TR-2 and $12 \beta$-hydroxyverruculogen TR-2, as well as the commercial fungicides carbendazim and hymexazol. In addition, this compound has a 2-methylpropan-2-ol group at C-3, and it has higher antifungal activity than cyclotryprostatin $\mathrm{B}$ that has an isobutenyl group at $\mathrm{C}-3$. These observations suggest that the introduction of an $O$-Me group at $\mathrm{C}-13$ yields higher activity, regardless of the configuration of the hydroxy group at C-12. The 2-methylpropan-2-ol substituent at C-3 on ring $\mathrm{C}$ of this family also appears to be necessary for activity. 12,13dihydroxyfumitremorgin $\mathrm{C}$ from Aspergillus sp. SCSIOInd09F01, A. fumigatus 30402dZa and Pseudallescheria sp. MFB262 belongs to the fumitremorgin class that has a similar structure to $12 \beta$-hydroxy$13 \alpha$-methoxyverruculogen TR-2 (Luo et al. 2017; Watts et al. 2010; Zhang et al. 2007b). It exhibits weak antibacterial activity, but strong inhibitory activity towards M. tuberculosis and T. brucei with 50\% minimun inhibitory concentration $\left(\mathrm{MIC}_{50}\right)$ and $\mathrm{IC}_{50}$ values of 2.41 and $6.4 \mu \mathrm{M}$, respectively (superior to verruculogen and fumitremorgin $\mathrm{B}$ ), demonstrating that the peroxide ring is not the bioactive pharmacophore. Furthermore, comparing with cyclotryprostatin A underscores the importance of the C-12 $R$ configuration. 6-methoxyspirotryprostatin $\mathrm{B}$ from 
Table 5 Sulphur-free-non-prenylated indole DKPs with antibiotic activities

\begin{tabular}{lll}
\hline Name & Biosynthetic precursors & Antibiotic activity \\
\hline DKP isomers 1 and 2 & Cyclo-(Leu-norvaline) & Antileishmanial \\
Diphenylalazines A and C & Cyclo-(Phe-Phe) & Antiviral, antibacterial, antifungal \\
Penicillatide B & Cyclo-(Phe-Pro) & Antibacterial, antifungal \\
Pinodiketopiperazine A & Cyclo-(Phe-norvaline) & Antibacterial \\
Spirobrocazine C & Cyclo-(Phe-Phe) & Antibacterial \\
Trichocyclodipeptides A-C & Cyclo-(Orn-Orn) & Antibacterial, antifungal \\
Aspergilazine A & Dimer: cyclo-(Pro-Trp)-cyclo-(Pro-Trp) & Antiviral \\
Cristatumin E & Dimer: cyclo-(Val-Trp)-cyclo-(Val-Trp) & Antibacterial \\
Pestalazine A & Dimer: cyclo-(Phe-Trp)-cyclo-(Leu-Trp) & Antiviral \\
Haenamindole & $\beta$-Phe-cyclo-(Trp-Phe) & Insecticidal \\
2'-epi-fumiquinazoline D & ATA-cyclo-(Ala-Trp)-Ala & Insecticidal \\
Neosartoryadins A and B & ATA-cyclo-(Val-Trp)-Aib & Antiviral \\
3-hydroxyfumiquinazoline A & ATA-cyclo-(Ala-Trp)-Ala & Antifungal \\
\hline
\end{tabular}

Orn ornithine, Aib 2-aminoisobutyric acid

Aspergillus sydowi PFW1-13 and A. fumigatus $030402 \mathrm{dZa}$ belongs to the spirotryprostatin class of alkaloids (Zhang et al. 2008). This compound is active against $T$. brucei $\left(\mathrm{IC}_{50}=5.7 \mu \mathrm{M}\right)$, unlike its derivatives spirotryprostatin A, $\mathrm{N}$-Me-6-methoxyspirotryprostatin $\mathrm{B}$ and $N$-Me-spirotryprostatin A. Also, two tertbutyloxycarbonyl (BOC) derivatives of fumitremorgin C and tryprostatin B from A. fumigates MR2012 display potent activity against $S$. aureus and $B$. subtilis (MICs $=2.1-3.3 \mu \mathrm{g} \mathrm{ml}^{-1}$ ), more than the parent compounds and comparable to tetracycline (El-Gendy and Rateb 2015). Therefore, the introduction of a BOC group significantly increases antibacterial activity against Gram-positive strains. It is likely that capping the $\mathrm{NH}$ groups with BOC groups makes these compounds more lipophilic, lowering their tendency to ionise, and thereby enhancing membrane penetration. Antibiotic activities of other prenylated indole DKPs and 18 sulphur-free-nonprenylated DKPs are listed in Tables 4 and 5 (Baran et al. 2005, 2006; Cai et al. 2012; Chen et al. 2017; Chu et al. 2010; Chunyu et al. 2017; Ding et al. 2008; Du et al. 2012; Guo et al. 2009; Hwang et al. 2016; Ishikawa et al. 2010; Kim et al. 2015; Koolen et al. 2012; Kozlovsky et al. 2001; Li et al. 2004, 2012b, 2013b; Meng et al. 2015b, 2016; Metwaly et al. 2015; Wang et al. 2013b; Youssef and Alahdal 2018; Yu et al. 2016).

\section{Highly $N$-methylated typical peptides}

Numerous structural modifications in the biosynthesis of antibiotic peptide products have been identified, of which $N$-methylation is the most common (Räder et al. 2018). Some studies have shown that $N$-methylation of amides removes $\mathrm{H}$-bond donor capacity, affects the backbone conformation, and introduces differences in lipophilicity and antibiotic properties, and the effects are more obvious with an increasing number of $N$ methylated sites (Chatterjee et al. 2006, 2012; Räder et al. 2018; van der Velden et al. 2017). As shown in Table 6,17 highly $N$-methylated typical peptides have been identified (represented by the structure of omphalotins in Fig. 4).

Phe-rich cordyheptapeptide A from Cordyceps sp. BCC1788 and BCC 16173 exhibits potent activity against $P$. falciparum $\left(\mathrm{IC}_{50}=3.8-5.35 \mu \mathrm{M}\right)$, while the B form has an $N$-Me-Phe residue instead of the $N$ Me-Tyr in A and is inactive, suggesting that the hydroxyl group in the aromatic ring is crucial for the antimalarial activity of this class (Isaka et al. 2007; Rukachaisirikul et al. 2006). Also, the A form is active against eight microbial strains, especially the Gramnegative bacteria P. aeruginosa and Klebsiella pneumoniae, as well as the dermatophytes Trichophyton mentagrophytes and Microsporum audouinii (MICs $=6 \mu \mathrm{g} \mathrm{ml}^{-1}$; the diameters of inhibition zones: DIZs $=25,26,20$ and $22 \mathrm{~mm}$, respectively), 
(a)<smiles></smiles>

(b)<smiles>[R]c1ccc2[nH]c(C(C)(C)C=C)c(C=C3NC(=O)C(=S)NC3=O)c2c1</smiles>

(c)<smiles>[R20]C(c1[nH]c2ccccc2c1C(=O)[C@H]1NC(=O)[C@H](C)NC1=O)C(C)(C)C=C</smiles>

(d)

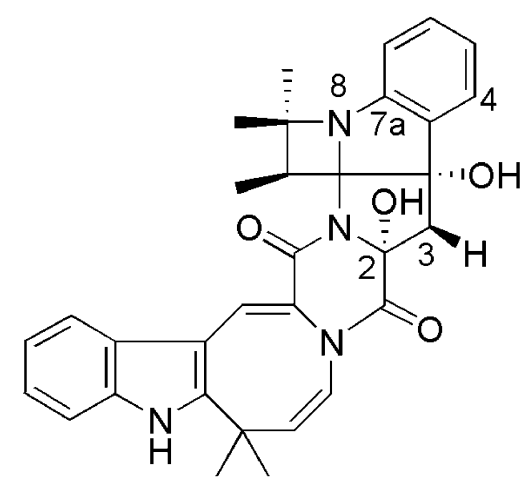

(e)

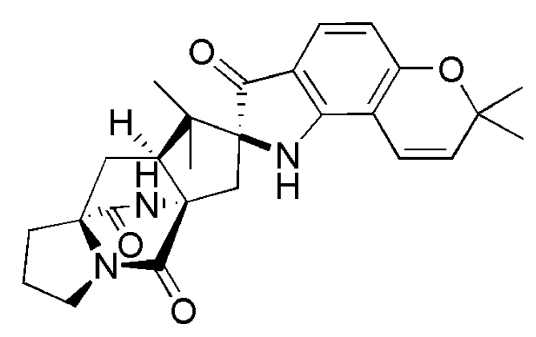

Fig. 3 Structure of partial sulphur-free prenylated indole DKPs. a Brevianamide $\mathrm{S}$. b Rubrumlines $\mathrm{D}\left[\mathrm{R}_{1}=\mathrm{CH}_{2} \mathrm{CH}(\mathrm{OH}) \mathrm{C}\right.$ $(\mathrm{OH})\left(\mathrm{CH}_{3}\right)_{2}$ ] and neoechinulin $\mathrm{B}\left(\mathrm{R}_{1}=\mathrm{H}\right)$. c Rubrumlines $\mathrm{M}$ $\left(\mathrm{R}_{2}=\mathrm{H}\right)$ and $\mathrm{N}\left(\mathrm{R}_{2}=\mathrm{CH}_{3}\right)$. d Okaramine Q. e Speramides A. f Tardioxopiperazine A. g cyclo- $N$-Me-anthranilic acid- $N$ - (f)<smiles>[Y14]C1NC(=O)[C@H](C)NC1=O</smiles>

(g)<smiles>C=CC(C)(C)[C@]1(CC2NC(=O)c3ccccc3N(C)C2=O)C(=O)N(O)c2ccccc21</smiles>

(h)

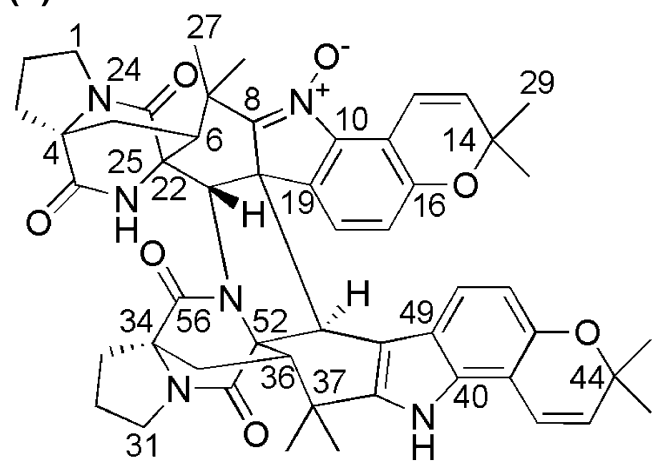

(i)

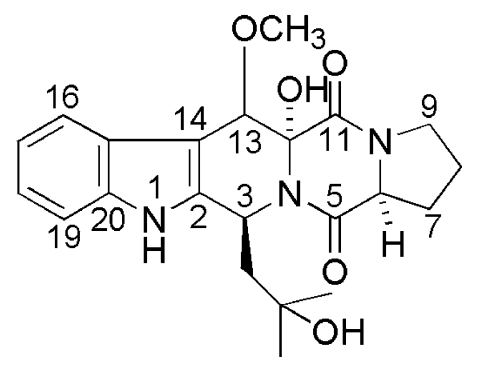

hydroxy-2-one-3-isopentenyl-Trp. h Waikialoid A. i 12 $\beta$-hydroxy13 $\alpha$-methoxyverruculogen TR-2 (Song et al. 2012; Chen et al. 2015; Shiono et al. 2000; Chang et al. 2016; Du et al. 2012; Zhou et al. 2014; Wang et al. 2012; Li et al. 2012b) 
Table 6 Highly $N$-methylated typical peptides with antibiotic activities

\begin{tabular}{|c|c|c|}
\hline Name & Sequence & Antibiotic activity \\
\hline Cordyheptapeptide A & $N$-Me-Phe*-Pro- $N$-Me-Gly-Phe- $N$-Me-Tyr-Ile-Leu* & Antimalarial, antibacterial, antifungal \\
\hline IB-01212 & $\begin{array}{l}N, N \text {-diMe-Leu-Ser*- } N \text {-Me-Leu- } N \text {-Me-Phe-Ser }(N, N \text {-diMe- } \\
\text { Leu)- } N \text {-Me-Leu- } N \text {-Me-Phe* }\end{array}$ & Antileishmanial \\
\hline Omphalotins $\mathrm{E}$ and $\mathrm{F}$ & $\begin{array}{l}N \text {-Me-Ile*- } N \text {-Me-Gly-Val- } N \text {-Me-Ile- } N \text {-Me-Gly-Trp derive/ } \\
N \text {-hydroxy-Trp derive- } N \text {-Me-Val-Ile- } N \text {-Me-Val- } N \text {-Me-Val- } \\
N \text {-Me-Gly- } N \text {-Me-3-hydroxy-Val* }\end{array}$ & Nematicidal \\
\hline Omphalotin G & $\begin{array}{l}N \text {-Me-Ile*- } N \text {-Me-2-hydroxy-Gly-Val- } N \text {-Me-Ile-Sar- } N \text { - } \\
\text { hydroxy-Trp derive- } N \text {-Me-Val-Ile- } N \text {-Me-Val- } N \text {-Me-Val- } N \text { - } \\
\text { Me-Gly- } N \text {-Me-3-hydroxy-Val* }\end{array}$ & \\
\hline Pseudoxylallemycin A & Phe*-N-Me-Leu-Phe- $N$-Me-Leu* & Antibacterial, antimycobacterial, anti- \\
\hline Pseudoxylallemycin B & $\begin{array}{l}O \text {-(buta-2,3-dienyl)-Tyr*-N-Me-Leu- } O \text {-(buta-2,3-dienyl)- } \\
\text { Tyr- } N \text {-Me-Leu* }\end{array}$ & $\begin{array}{l}\text { trypanosomal, antileishmanial, } \\
\text { antimalarial }\end{array}$ \\
\hline Pseudoxylallemycin $\mathrm{C}$ & Phe*-N-Me-Leu- $O$-(buta-2,3-dienyl)-Tyr- $N$-Me-Leu* & \\
\hline Pseudoxylallemycin D & $\begin{array}{l}\text { Phe*-N-Me-Leu-5-hydroxy-O-(buta-2,3-dienyl)-Tyr- } N \text {-Me- } \\
\text { Leu* }\end{array}$ & \\
\hline Verrucamides A and B & $\begin{array}{l}N \text {-Me-Phe*-Gly-Val- } N \text {-Me-Thr-Val- } N \text {-Me-Thr-Val- } N \text {-Me- } \\
\text { Ala-Gly-Ile- } N \text {-Me-Ser- } N \text {-Me-Ile/ } N \text {-Me-Val-Ser-Val* }\end{array}$ & Antibacterial \\
\hline Verrucamides C and D & $\begin{array}{l}N \text {-Me-Phe*-Gly-Val- } N \text {-Me-Thr-Val- } N \text {-Me-Thr-Val- } N \text {-Me- } \\
\text { Ala-Gly-Val- } N \text {-Me-Ser- } N \text {-Me-Ile/ } N \text {-Me-Val-Ser-Val* }\end{array}$ & \\
\hline Talaropeptide A & $\begin{array}{l}N \text {-Me-Ala- } N \text {-Me-Val-Val-Thr- } N \text {-Me-Val-Pro- } N \text {-Me-Val- } N \text { - } \\
\text { Me-Val- } N \text {-Me-Phe- } N \text {-Me-Ile-Leu }\end{array}$ & Antibacterial \\
\hline Talaropeptide B & $\begin{array}{l}N \text {-Me-Ala- } N \text {-Me-Val-Val-Thr-Val- } N \text {-Me-Val-Pro- } N \text {-Me-Val- } \\
N \text {-Me-Val- } N \text {-Me-Phe- } N \text {-Me-Ile-Leu }\end{array}$ & \\
\hline Clonostachysins A and B & $\begin{array}{l}N \text {-Me-Gly*- } N \text {-Me-Leu-Pro- } O \text {-Me-Tyr-Ala- } N \text {-Me-Val/ } N \text {-Me- } \\
\text { Ile- } N \text {-Me-Leu- } N \text {-Me-Ile- } N \text {-Me-Ala* }\end{array}$ & Antimicroalgal \\
\hline
\end{tabular}

Trp derive tricyclic tryptophan derivative, 3a-hydroxy-pyrrolidino[2,3-b]indole-2-carboxylic acid

*Denoting the linkage position of the ring formation

with potency greater than gatifloxacin and griseofulvin (Kumar et al. 2017). In addition, cordyheptapeptide A displays greater bioactivity against these pathogenic microbes than its linear form due to a reduction in the degree of freedom for each constituent within the ring resulting from cyclisation of the peptide. IB-01212 from marine sponge-derived Clonostachys sp. ESNA-A009 features $C_{2}$ symmetry, and displays Leishmanicidal activity in the low micromolar range against promastigotes Leishmania pifanoi and amastigote forms of the parasite $L$. donovani, with greater activity against amastigotes (Cruz et al. 2006; Luque-Ortega et al. 2010). Ten derivatives of IB-01212 were synthesised through the original ester linkages between the hydroxyl groups of Ser residues and the $C$-terminal carboxyl group of $N$ Me-Phe replaced by a thioester (Ser $\rightarrow$ Cys) or an amide such as Ser $\rightarrow$ 2,3-diaminobutyric acid (Dab), 2,3-diaminopropionic acid (Dap), ornithine (Orn) or Lys. In general, monosubstituted analogs are more active than bisubstituted ones, suggesting that perturbation of $\mathrm{C}_{2}$ symmetry improves leishmanicidal activity. Therefore, the nature of the two hydroxyl groups that form the original peptide linkages of the two tetrapeptide moieties modulates activity. Furthermore, three analogs display higher activity against amastigotes than IB-01212, indicating that ring size affects leishmanicidal activity. Ruling out massive disruption of the plasma membrane suggested the involvement of intracellular targets such as mitochondrial dysfunction that eventually causes parasite death through an apoptotic-like process. Oxidatively modified omphalotins E-G from Omphalotus olearius TA90170 contain a tricyclic Trp derivative, and all exhibit strong and selective nematicidal activity against Meloidogyne incognita, especially G 


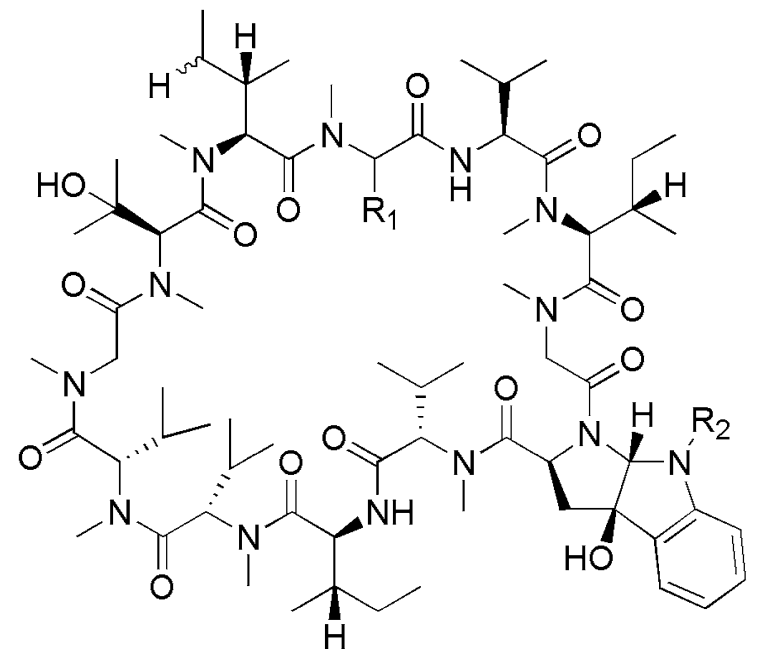

Fig. 4 Structure of omphalotins E-G (highly $N$-methylated typical peptides). E: $\mathrm{R}_{1}, \mathrm{R}_{2}=\mathrm{H} ; \mathrm{F}: \mathrm{R}_{1}=\mathrm{H}, \mathrm{R}_{2}=\mathrm{OH} ; \mathrm{G}$ : $\mathrm{R}_{1}=\mathrm{OH}, \mathrm{R}_{2}=\mathrm{OH}$ (Liermann et al. 2009)

$\left(\mathrm{LD}_{50}=1 \mu \mathrm{g} \mathrm{ml}^{-1} ; \quad \mathrm{LD}_{90}=2 \mu \mathrm{g} \mathrm{ml}^{-1}\right)$, which is more active than ivermectin and comparable to its lipopeptide analogs omphalotins $\mathrm{H}$ and I (Liermann et al. 2009). It was suggested that both hydroxylation at $\mathrm{N}$-Me-Gly and Trp derivatisation may improve nematicidal effects, while $O$-acetyl and $O$-(3-hydroxy3-Me-butyl) groups in $\mathrm{N}$-Me-Gly and $\mathrm{N}$-Me-Ile residues do not appear to influence the activity of the omphalotin class.

Pseudoxylallemycins A-D from Pseudoxylaria sp. X802 contain an alternating pattern of $N$-methylation, with $N$-Me groups present at Leu but not Phe or Tyr residues (Guo et al. 2016). Specifically, B-D also carry one or two allenyl modifications at the aromatic ring of Tyr moieties. All show moderate activity against $P$. aeruginosa and Mycobacterium vaccae. A$\mathrm{C}$ also display antiparasitic activity against Trypanosoma brucei rhodesiense, Trypanosoma cruzi, $L$. donovani and P. falciparum, especially $\mathrm{B}$ which is the most potent $\left(\mathrm{IC}_{50}=0.64,1.88,2.01\right.$ and $1.23 \mu \mathrm{M}$, respectively), indicating that allenyl groups significantly affect antiparasitic activity (Guo et al. 2018). Verrucamides A-D from Myrothecium verrucaria XZ04-18-2 feature six $N$-methylated amino acid residues (Zou et al. 2011). They show significant activity against $S$. aureus, with A the most potent $\left(\mathrm{IC}_{50}=3.59 \mu \mathrm{g} \mathrm{ml}^{-1} ; \quad \mathrm{MIC}=10 \mu \mathrm{g} \mathrm{ml}^{-1}\right)$. These findings demonstrated that extension of the carbon chain of $N-\mathrm{Me}-\mathrm{Val}$ is conducive to maintaining higher antibacterial activity. Two 11-12 residue linear peptides, talaropeptides A and B from Talaromyces sp. CMB-TU011 lack mammalian cell cytotoxicity but exhibit promising growth inhibitory activity against $B$. subtilis $\left(\mathrm{IC}_{50}=1.5\right.$ and $3.7 \mu \mathrm{M}$, respectively), indicating that enhanced activity is due to $\mathrm{N}$-methylation of the Val residue in A (Dewapriya et al. 2018). Antimicroalgal activity of clonostachysins is shown in Table 6 (Adachi et al. 2005).

\section{Non-highly $N$-methylated typical peptides}

In addition to highly $N$-methylated typical peptides, since 2000, another 32 typical peptide products have been reported (Table 7). Figures 5 and 6 show the structures of arborcandins and calpinactam as representative examples. Seven apicidin-like compounds named apicidins $\mathrm{A}-\mathrm{C}, \mathrm{D}_{1}-\mathrm{D}_{3}$ and $\mathrm{F}$ have been identified. Apicidins $\mathrm{A}-\mathrm{C}$ and $\mathrm{D}_{1}-\mathrm{D}_{3}$ from Fusarium pallidoroseum MF6040 and Fusarium sp. MF6058 have a $\mathrm{C}_{8}$-keto or $\mathrm{C}_{8} / \mathrm{C}_{9}$-hydroxyl group at a 2-aminodecanoic acid (Ada) substituent linked to a $\beta$-turn amino acid residue, namely piperazic acid (Pip) or Pro (Singh et al. 2001, 2002). These compounds show potent and selective activity against $P$. falciparum and Eimeria tenella. Apicidins $\mathrm{A}$ and $\mathrm{D}_{1}$ are among the most active compounds of the series $\left(\mathrm{IC}_{50}=59\right.$ and $34 \mathrm{nM}$; MICs $=52$ and $13 \mathrm{nM}$ ). Additionally, two synthesised C-8 hydroxyl compounds were over tenfold less active than apicidins $A$ and $D_{1}$, and chemical modification of the Trp residue led to compounds exhibiting significant parasite selectivity. These results indicate that the C- 8 keto group and Trp are both critical for activity. Apicidins B and C are also strongly and selectively active against Besnoitia jellisoni (MICs $=12.8$ and $0.8 \mathrm{nM}$, respectively). Apicidin $\mathrm{F}$ has a 2-aminooctanedioic acid instead of Ada incorporated into the tetrapeptide, and it displays good in vitro activity against $P$. falciparum $\left(\mathrm{IC}_{50-}\right.$ $=0.67 \mu \mathrm{M})($ von Bargen et al. 2013). Apicidins are potent and broad spectrum antiprotozoal agents that reversibly inhibit histone deacetylase (HDAC) activity (Kwon et al. 2003; Singh et al. 2001). HDACs regulate gene transcription by controlling the dynamic acetylation and deacetylation of Lys residues. Blockade of deacetylation causes hyperacetylation of histones, leading to untimely cell death. Arborcandins A-F from the fungus SANK17397 contain one 2-amino-5- 
Table 7 Non-highly $N$-methylated typical peptides with antibiotic activities

\begin{tabular}{|c|c|c|}
\hline Name & Sequence & Antibiotic activity \\
\hline Apicidins A and B & Trp*/N-methoxy-Trp*-Ile-Pip/Pro-AODA* & \multirow{4}{*}{$\begin{array}{l}\text { Antimalarial, anti-Eimeria, } \\
\text { anti-Besnoitia }\end{array}$} \\
\hline Apicidin $\mathrm{C}$ & $N$-methoxy-Trp*-Val-Pip-AODA* & \\
\hline Apicidins $\mathrm{D}_{1}-\mathrm{D}_{3}$ & $N$-methoxy-Trp*-Ile-Pip-AOHA*/AHDA*/ANDA* & \\
\hline Apicidin F & $N$-methoxy-Trp*-Phe-Pip-AOEA* & \\
\hline Arborcandins A-D & $\begin{array}{l}\text { AHTA*-Gly- } \beta \text {-Ala-ATDA/AHPA/AH } \\
\text { HA/AOHDA-Asn-Asn-Ala-4-hydroxy-Gln-Thr-Thr* }\end{array}$ & \multirow[t]{2}{*}{ Antifungal } \\
\hline Arborcandins $\mathrm{E}$ and $\mathrm{F}$ & $\begin{array}{l}\text { APDA*/AHAA*-Gly- } \beta \text {-Ala-AHHA-Asn- } \\
\text { Asn-Ala-4-hydroxy-Gln-Thr-Thr* }\end{array}$ & \\
\hline LG53-R5 & Leu*-Leu-Leu-Leu-Val* & Antifungal \\
\hline Malformins $\mathrm{A}_{1}$ and $\mathrm{A}_{2}$ & S**_Cys*-Val-Leu-Ile/Val-Cys*-S** & \multirow{2}{*}{$\begin{array}{l}\text { Antimalarial, anti-trypanosomal, } \\
\text { anti-TMV, anti-HIV-1 }\end{array}$} \\
\hline Malformins $\mathrm{B}_{2}$ and $\mathrm{C}$ & S**_Cys*-Val-Val/Leu-Leu-Cys*_S** & \\
\hline Malformin E & S**-Cys*-Ile-Val-Leu-Cys*-S** & Antibacterial, antifungal \\
\hline Serinocyclin A & Acc*-4-hydroxy-Pro-Ser-4-hydroxy-Lys- $\beta$-Ala-Ser-Ser* & Antimosquito \\
\hline Xylapeptides A and B & $N$-Me-Phe*-Val-Ala-Leu-Pip*/Pro* & Antibacterial, antifungal \\
\hline Aspergillipeptide D & $N$-Me-Tyr*-Val-Pro- $O$-Me-Tyr- $O$-Me-Tyr* & \multirow[t]{2}{*}{ Anti- ${ }^{16} \mathrm{HSV}-1$} \\
\hline Aspergillipeptide E & Tyr-Trp-Val & \\
\hline Calpinactam & Phe-Leu-His-Glu-Ile-Lys & Antimycobacterial \\
\hline Trichodermamide B & A modified dipeptide & Antifungal, antibacterial \\
\hline CAFT122-1 & Ile*-Leu-Leu-Leu-Leu* & Antifungal \\
\hline Tetrapeptides K38 and E33 & Pro*/Gly*-Tyr/Phe-Pro-Tyr* & Antifungal \\
\hline Pentapeptide $75-1-3-1$ & $N$-Me-Phe*-Val-Ile-Leu-Pro* & Synergistic antifungal \\
\hline Lajollamide A & $N$-Me-Leu*-Leu-Leu-Leu-Val* & Antibacterial \\
\hline Tetrapeptide BAFC 3291 & Phe-Val-Val-Tyr & Antifungal, antibacterial \\
\hline
\end{tabular}

Pip piperazic acid, AODA 2-amino-8-oxodecanoic acid, AOHA 2-amino-8-oxo-9-hydroxy-decanoic acid, AHDA 2-amino-8-hydroxydecanoic acid, ANDA 2-amino-9-hydroxy-decanoic acid, AOEA 2-aminooctanedioic acid, AHTA 2-amino-5-hydroxy-tetradecanoic acid, ATDA 2-amino-10-hydroxy-tetradecanoic acid, AHPA 2-amino-10-hydroxy-pentadecanoic acid, AHHA 2-amino-10-hydroxyhexadecanoic acid, AOHDA 2-amino-10-oxohexadecanoic acid, APDA 2-amino-5-hydroxy-pentadecanoic acid, AHAA 2-amino-5hydroxy-hexadecanoic acid, TMV Tobacco mosaic virus, Acc 1-aminocyclopropane-1-carboxylic acid, $H S V$ - 1 herpes simplex virus type 1

*, **Denoting the linkage position of the first and second ring formation, respectively

hydroxyl acid (AHA) and one 2-amino-10-hydroxyl/ 10-oxo acid (AHOA), connected to Gly and $\beta$-Ala residues, respectively (Ohyama et al. 2000, 2003). They possess strong growth inhibitory activity against A. fumigatus, of which C, E and F are the most potent, with minimum effective concentrations (MECs) of $0.063 \mu \mathrm{g} \mathrm{ml}^{-1}$, considerably superior to pneumocan$\operatorname{din} \mathrm{A}_{0}$; However, against Candida spp. (C. albicans, Candida parapsilosis and Candida tropicalis), $\mathrm{F}$ is the most potent $\left(\mathrm{MICs}=0.25-2 \mu \mathrm{g} \mathrm{ml}^{-1}\right.$ ), comparable to the MICs of fluconazole (Ohyama et al. 2000). This suggests that the hydroxyl group and carbon chain extension of the two unusual AHA and AHOA units are important for enhancing the antifungal activity of arborcandins. In addition, activity of these compounds against Candida spp. is due to inhibition of 1,3- $\beta$ glucan synthase, and they cause a change in the hyphal growth of A. fumigates (Ohyama et al. 2000, 2004).

LG53-R5 from Fusarium decemcellulare LG53 and Fusarium sp. R5 exhibits broad spectrum antifungal activity against $C$. gloeosporioides, C. musae and $F$. oxysporum, among which activity toward $F$. oxysporum ( $\mathrm{MIC}=23 \mu \mathrm{M}$ ) is superior to carbendazim that is used globally as an agricultural and horticultural fungicide ( $\mathrm{Li}$ et al. 2016b; Zhu et al. 2018). Malformins $A_{1}$ (A. niger 56-39 and Aspergillus tubingensis FJBJ11), $\mathrm{A}_{2}$ (A. niger 56-39), $\mathrm{B}_{2}$ (A. niger 56-30), $\mathrm{C}$ (A. niger AN-1, \# 94-1212 and SCSIO Jcsw6F30) and E (Aspergillus tamari FR02) are cyclicpentapeptides with a disulphide bond between 


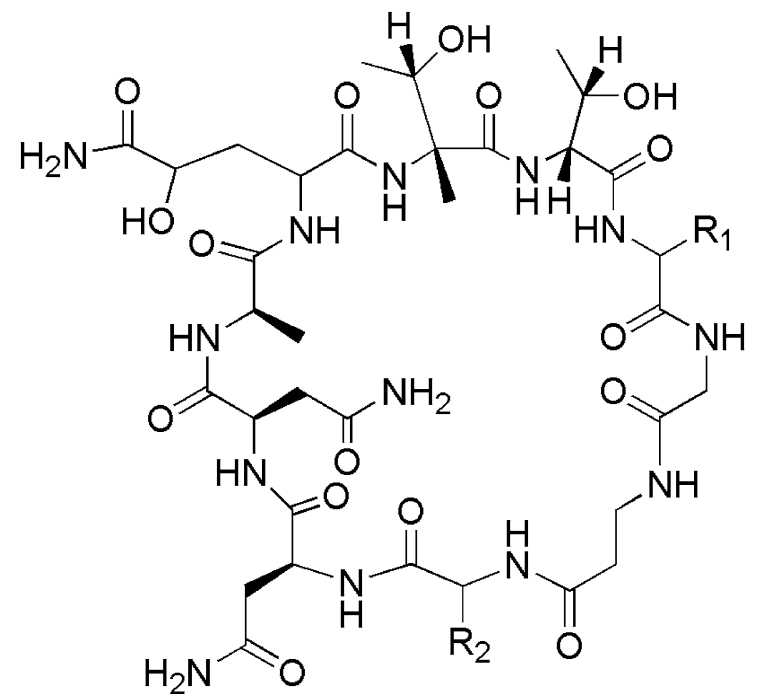

Fig. 5 Structure of arborcandins A-F (non-highly $N$-methylated typical cyclic peptides). A: $\mathrm{R}_{1}=\left(\mathrm{CH}_{2}\right)_{2} \mathrm{CH}(\mathrm{OH})\left(\mathrm{CH}_{2}\right)_{8-}$ $\mathrm{CH}_{3}, \quad \mathrm{R}_{2}=\left(\mathrm{CH}_{2}\right)_{7} \mathrm{CH}(\mathrm{OH})\left(\mathrm{CH}_{2}\right)_{3} \mathrm{CH}_{3} ; \quad \mathrm{B}: \mathrm{R}_{1}=\left(\mathrm{CH}_{2}\right)_{2} \mathrm{CH}$ $(\mathrm{OH})\left(\mathrm{CH}_{2}\right)_{8} \mathrm{CH}_{3}, \quad \mathrm{R}_{2}=\left(\mathrm{CH}_{2}\right)_{7} \mathrm{CH}(\mathrm{OH})\left(\mathrm{CH}_{2}\right)_{4} \mathrm{CH}_{3} ; \mathrm{C}: \mathrm{R}_{1}=$ $\left(\mathrm{CH}_{2}\right)_{2} \mathrm{CH}(\mathrm{OH})\left(\mathrm{CH}_{2}\right)_{8} \mathrm{CH}_{3}, \mathrm{R}_{2}=\left(\mathrm{CH}_{2}\right)_{7} \mathrm{CH}(\mathrm{OH})\left(\mathrm{CH}_{2}\right)_{5} \mathrm{CH}_{3}$; D: $\mathrm{R}_{1}=\left(\mathrm{CH}_{2}\right)_{2} \mathrm{CH}(\mathrm{OH})\left(\mathrm{CH}_{2}\right)_{8} \mathrm{CH}_{3}, \mathrm{R}_{2}=\left(\mathrm{CH}_{2}\right)_{7} \mathrm{CO}\left(\mathrm{CH}_{2}\right)_{5} \mathrm{CH}_{3}$; $\mathrm{E}: \mathrm{R}_{1}=\left(\mathrm{CH}_{2}\right)_{2} \mathrm{CH}(\mathrm{OH})\left(\mathrm{CH}_{2}\right)_{9} \mathrm{CH}_{3}, \mathrm{R}_{2}=\left(\mathrm{CH}_{2}\right)_{7} \mathrm{CH}(\mathrm{OH})\left(\mathrm{CH}_{2}\right)_{5}$ $\mathrm{CH}_{3}$; F: $\mathrm{R}_{1}=\left(\mathrm{CH}_{2}\right)_{2} \mathrm{CH}(\mathrm{OH})\left(\mathrm{CH}_{2}\right)_{10} \mathrm{CH}_{3}, \mathrm{R}_{2}=\left(\mathrm{CH}_{2}\right)_{7} \mathrm{CH}(\mathrm{OH})$ $\left(\mathrm{CH}_{2}\right)_{5} \mathrm{CH}_{3}$ (Ohyama et al. 2000, 2003)<smiles>CC[C@H](C)[C@H](NC(=O)[C@H](CCC(=O)O)NC(=O)[C@H](Cc1c[nH]cn1)NC(=O)[C@H](CC(C)C)NC(=O)[C@H](N)Cc1ccccc1)C(=O)NC1CCCCNC1=O</smiles>

Fig. 6 Structure of calpinactam (non-highly $N$-methylated typical linear peptides) (Koyama et al. 2010a, b)

two cysteine thiols. Malformins $\mathrm{A}_{1}, \mathrm{~A}_{2}, \mathrm{~B}_{2}$ and $\mathrm{C}$ exhibit potent anti-P. falciparum $\left(\mathrm{IC}_{50}=0.056\right.$, $0.095,0.019$ and $0.07 \mu \mathrm{g} \mathrm{ml}^{-1}$, respectively) and anti-T. brucei brucei $\left(\mathrm{IC}_{50}=0.19,0.56,0.0052\right.$ and $0.0016 \mu \mathrm{g} \mathrm{ml}^{-1}$, respectively) activities, equal to those of pentamidine and artemether, but more active than chloroquine (Sugawara 1990; Tan et al. 2015; Varoglu and Crews 2000; Zhou et al. 2016). Moreover, a modified malformin with a less hindered Ala instead of the Leu present in malformin $\mathrm{C}$ exhibits reduced activity against both parasites, as do two disulphide bond-free malformin $\mathrm{C}$ derivatives
(Kojima et al. 2009). These results indicate that the disulphide bond is essential, and branched amino acids (e.g. Leu, Ile and Val) are also crucial components. Interestingly, malformin $\mathrm{A}_{1}$ inhibits Tobacco mosaic virus (TMV) replication and infection, and is more active than the positive control ningnamycin (Tan et al. 2015). Studies have indicated that the anti-TMV properties of malformin $\mathrm{A}_{1}$ could possibly be due, at least in part, to its ability to modulate ethylene production, which in turn elicits defence mechanisms in host plants. Malformin C exerts potent anti-HIV-1 activity via SF162 infection in TZM-bl cells, comparable to that of abacavir, a nucleoside reverse transcriptase inhibitor, and ADS-J1, an effective HIV-1 entry inhibitor (Zhou et al. 2016). Malformin E displays significant growth inhibition against $S$. aureus, B. subtilis, E. coli and P. aeruginosa, more active than gentamicin (Ma et al. 2016). It also has strong antifungal activity against Penicillium chrysogenum, C. albicans and F. solani, equivalent to nystatin. Ser-rich serinocyclin A from Metarhizium anisopliae has a cyclopropane amino acid residue along with a charged lysyl side chain and multiple hydroxyl groups that contribute to the polar nature of the compound (Krasnoff et al. 2007). This compound can produce a sublethal locomotory defect in mosquito larvae $\left(\mathrm{EC}_{50}=59 \mathrm{ppm}\right)$. Xylapeptides $\mathrm{A}$ and $\mathrm{B}$ from Xylaria sp. \#GDG-102 have a Pip moiety and Pro residue, respectively ( $\mathrm{Xu}$ et al. 2017). The A form shows moderate inhibitory activity only against $B$. subtilis and B. cereus (MICs $=12.5 \mu \mathrm{g} \mathrm{ml}^{-1}$ ), while $B$ exhibits stronger and broader antimicrobial activity against B. subtilis, B. cereus, B. megaterium, Micrococcus luteus, S. aureus, Shigella castellani and $C$. albicans. This suggests that the Pip and Pro moieties play different roles in antimicrobial activity.

Aspergillipeptide D with two $O$-Me-Tyr and one $N$ Me-Tyr residues, and the linear tripeptide aspergillipeptide E from Aspergillus sp. SCSIO 41501, display antiviral activity against herpes simplex virus type 1 (HSV-1) with $\mathrm{IC}_{50}$ values of 9.5 and $19.8 \mu \mathrm{M}$, respectively, and $\mathrm{D}$ also shows antiviral activity against acyclovir-resistant clinical isolates of HSV-1-106 and HSV-1-153 (12.5 $\mu \mathrm{M})$ with a $\sim 50 \%$ inhibition rate (Ma et al. 2017). The cyclic structure is important for maintaining high anti-HSV-1 activity. Calpinactam from Mortierella alpina FKI-4905 has a caprolactam moiety at its $C$-terminus and was found to inhibit the growth of M. smegmatis 
$\left(\mathrm{MIC}=0.78 \mu \mathrm{g} \mathrm{ml}^{-1} ; \mathrm{DIZ}=22 \mathrm{~mm}\right.$ at $5 \mu \mathrm{g} /$ disk $)$, more effective than isoniazid, rifampicin, kanamycin, pyrazinamide, lysocin E and propeptin (Koyama et al. 2010a, b; Yagi et al. 2017). Using an in vivo silkworm infection model for $M$. smegmatis, calpinactam exerted moderate therapeutic effects, and it shows moderate inhibition of the growth of $M$. tuberculosis (Yagi et al. 2017). Meanwhile, a series of synthesised calpinactam derivatives with different amino acids exhibited no or significantly reduced antimycobacterial activity, revealing that the side chains, stereochemistry, and the entire peptide chain length are all critical for antimycobacterial activity (Koyama et al. 2010a, b; Nagai et al. 2012). Preliminary analysis of the mechanism of action indicated that calpinactam might act on the cell wall biosynthetic steps in mycobacteria (Koyama et al. 2010b). Trichodermamide B, a modified linear dipeptide from Trichoderma virens CNL910 and Halimeda sp.-derived CNK266, possesses a cyclic $O$-alkyl-oxime functionality incorporated into a six-membered ring (Garo et al. 2003). It exhibits moderate antimicrobial activity against amphoterocin-resistant $C$. albicans, MRSA and VRE, whereas its dechlorinated derivative trichodermamide A is completely inactive. This suggests that the chlorine atom is an essential part of the pharmacophore. Indeed, chlorination is known to play an essential role in the antibiotic activity of numerous structurally diverse natural products (e.g. vancomycin and chloramphenicol). Antibiotic activities of other non-highly $N$-methylated typical peptides are shown in Table 7 (Bertinetti et al. 2009; Gulder et al. 2012; Huang et al. 2014; Talontsi et al. 2012; Wu et al. 2011).

\section{Conclusions}

In this review, we summarise 186 diverse fungiderived DKPs and typical peptides reported since 2000, and focus of the structural characteristics, SAR and mechanisms of action of 107 of them. These features contribute significantly to antibiotic activity. In the biosynthesis, genetics, total synthesis and research methodologies has grown considerably over this time. However, only biosynthases of tardioxopiperazines and neoechinulins have been reported (Table 1), consistent with the claim that research on DKP biosynthesis tends to move along at a slow pace compared with organic synthesis. With the rapid development of modern biotechnological approaches and high-throughput sequencing technologies, our understanding of the molecular and enzymatic mechanisms of DKP biosynthesis is deepening. Therefore, predictably, more and more NRPSs will be identified, and novel DKPs with high antibiotic activity and low toxicity will likely be designed and tested. Two methods are most often used for the exploration of natural DKPs; traditional approaches and molecular detection. All DKPs mentioned in this review were identified using the former, classical approach, that generally proceeds as follows: (1) fermented cultures are extracted with organic solvent (e.g. acetone, EtOAc, methyl ethyl ketone, methanol, ethanol); (2) extracts are concentrated in vacuo and subjected to column chromatography (e.g. silica gel, Sephadex LH-20, Lobar LiChroprep RP-18) or thin layer chromatography on silica gel; (3) active fractions are further separated by reversed-phase high performance liquid chromatography (HPLC); (4) structures are determined mainly by nuclear magnetic resonance (NMR), electrospray ionization mass spectrometry (ESI-MS), infrared ray (IR) or gas chromatographymass spectrometer (GC-MS). Meanwhile, molecular detection is based on the relationship between DKP biosynthase sequences and structures: (1) biosynthesis-related DKP genes are cloned by PCR amplification using conserved primer pairs and phylogenetic analysis of sequences reveals the structures of DKPs; (2) genes are also screened by phylogenetic analysis of "cryptic gene clusters" in the genome, and structures are derived based on ten conserved specific amino acid residues of adenylation domains in NRPSs.

SAR analysis suggests that the presence of specific groups (e.g., di- and tetrasulphide bridges, double bonds, azocine rings, certain amino acids and their configuration, keto groups, disulfide bonds, and caprolactam), substitutions at some pharmacophore sites (e.g., $O-\mathrm{Me}$, hydroxyl, 2-methylpropan-2-ol, tertbutyloxycarbonyl, allenyl, the number of $N$-methylations, chlorination and perturbation of $\mathrm{C}_{2}$ symmetry), dimerisation and its linkage sites, and cyclic structures and ring size are important for endowing activity. Mechanisms of action can be summarised as follows: (1) inhibition of protein biosynthesis for aspirochlorine (a halogenated spiro compound); (2) inhibiting the production of virulence factors for graphiumins; (3) inhibition of ATP synthesis in mitochondria, 
causing an uncoupling of oxidative phosphorylation and depression of respiration for emestrins; (4) perturbing the proteome and inducing redox stress in fungi for gliotoxin; (5) inhibiting mycelial growth by inducing curling and swelling, and inducing morphological changes in mycelia for diketopiperazine M-3; (6) binding to hemagglutinin in the influenza envelope, and disrupting its interaction with the sialic acid receptor and the attachment of viruses to host cells for neoechinulin B and rubrumlines; (7) targeting glutamate-gated chloride channels in Bombyx mori for okaramines; (8) inhibiting cell adherence, hyphal development, and biofilm assembly during the early stages of surface colonisation for waikialoids; (9) targeting the plasma membrane, causing mitochondrial dysfunction that eventually causes parasite death via an apoptotic-like process for IB-01212; (10) inhibition of enzymes (e.g. HDAC for apicidins and 1,3 - $\beta$-glucan synthase for arborcandins); (11) modulating ethylene production for malformin $\mathrm{A}_{1}$; and (12) acting on cell wall biosynthesis in mycobacteria for calpinactam. However, research on SARs and mechanisms of action is limited and often poorly focused, and further detailed studies are clearly needed.

Regardless of future directions, some fungal DKPs and typical peptides can be regarded as promising candidates and lead compounds for drug development in agriculture and medicine due to their potent antimicrobial and antiprotozoal properties. However, to date, only cyclosporin A has been developed as an antifungal drug (Survase et al. 2011; Wang et al. 2017b). Therefore, effective research and development must be undertaken if novel pharmaceutical drugs and biocontrol agents are to be brought to market.

Acknowledgements This work was supported by grants from the National Natural Science Foundation of China (NSFC, Grant Nos. 31672530, U1704117 and 31800836), the Natural Science Foundation of Henan Province of China (Grant No. 182300410353) and the Doctoral Foundation of Henan University of Science and Technology (Grant No. 4022/13480021).

\section{Compliance with ethical standards}

Conflict of interest The authors declare no competing financial interest.

\section{References}

Adachi K, Kanoh K, Wisespongp P, Nishijima M, Shizuri Y (2005) Clonostachysins A and B, new anti-dinoflagellate cyclic peptides from a marine-derived fungus. J Antibiot (Tokyo) 58:145-150. https://doi.org/10.1038/ja.2005.17

Ali H, Ries MI, Nijland JG, Lankhorst PP, Hankemeier T, Bovenberg RA, Vreeken RJ, Driessen AJ (2013) A branched biosynthetic pathway is involved in production of roquefortine and related compounds in Penicillium chrysogenum. PLoS ONE 8:e65328. https://doi.org/10. 1371/journal.pone.0065328

Arora P, Wani ZA, Nalli Y, Ali A, Riyaz-Ul-Hassan S (2016) Antimicrobial potential of thiodiketopiperazine derivatives produced by Phoma sp., an endophyte of Glycyrrhiza glabra Linn. Microb Ecol 72:802-812. https://doi.org/10. 1007/s00248-016-0805-x

Baran PS, Guerrero CA, Hafensteiner BD, Ambhaikar NB (2005) Total synthesis of avrainvillamide $(\mathrm{CJ}-17,665)$ and stephacidin B. Angew Chem Int Ed Engl 44:3892-3895. https://doi.org/10.1002/anie.200500655

Baran PS, Hafensteiner BD, Ambhaikar NB, Guerrero CA, Gallagher JD (2006) Enantioselective total synthesis of avrainvillamide and the stephacidins. J Am Chem Soc 128:8678-8693. https://doi.org/10.1021/ja061660s

Belin P, Le Du MH, Fielding A, Lequin O, Jacquet M, Charbonnier JB, Lecoq A, Thai R, Courçon M, Masson C et al (2009) Identification and structural basis of the reaction catalyzed by CYP121, an essential cytochrome P450 in Mycobacterium tuberculosis. Proc Natl Acad Sci USA 106:7426-7431. https://doi.org/10.1073/pnas.0812191106

Belin P, Moutiez M, Lautru S, Seguin J, Pernodet JL, Gondry M (2012) The nonribosomal synthesis of diketopiperazines in tRNA-dependent cyclodipeptide synthase pathways. Nat Prod Rep 29:961-979. https://doi.org/10.1039/ c2np20010d

Bertinetti BV, Peña NI, Cabrera GM (2009) An antifungal tetrapeptide from the culture of Penicillium canescens. Chem Biodivers 6:1178-1184. https://doi.org/10.1002/ cbdv.200800336

Brase S, Encinas A, Keck J, Nising C (2009) Chemistry and biology of mycotoxins and related fungal metabolites. Chem Rev 109:3903-3990. https://doi.org/10.1021/ cr050001f

Byun HG, Zhang H, Mochizuki M, Adachi K, Shizuri Y, Lee WJ, Kim SK (2003) Novel antifungal diketopiperazine from marine fungus. J Antibiot (Tokyo) 56:102-106. https://doi.org/10.7164/antibiotics.56.102

Cai S, Kong X, Wang W, Zhou H, Zhu T, Li D, Gu Q (2012) Aspergilazine A, a diketopiperazine dimer with a rare $\mathrm{N}-1$ to C-6 Linkage, from a marine-derived fungus Aspergillus taichungensis. Tetrahedron Lett 53:2615-2617. https://doi. org/10.1016/j.tetlet.2012.03.043

Carberry S, Molloy E, Hammel S, O'Keeffe G, Jones GW, Kavanagh K, Doyle S (2012) Gliotoxin effects on fungal growth: mechanisms and exploitation. Fungal Genet Biol 49:302-312. https://doi.org/10.1016/j.fgb.2012.02.003

Chang YW, Yuan CM, Zhang J, Liu S, Cao P, Hua HM, Di YT, Hao XJ (2016) Speramides A-B, two new prenylated indole alkaloids from the freshwater-derived fungus 
Aspergillus ochraceus KM007. Tetrahedron Lett 57:4952-4955. https://doi.org/10.1016/j.tetlet.2016.09. 071

Chankhamjon P, Boettger-Schmidt D, Scherlach K, Urbansky B, Lackner G, Kalb D, Dahse HM, Hoffmeister D, Hertweck C (2014) Biosynthesis of the halogenated mycotoxin aspirochlorine in koji mold involves a cryptic amino acid conversion. Angew Chem Int Ed Engl 53:13409-13413. https://doi.org/10.1002/anie.201407624

Chatterjee J, Mierke D, Kessler H (2006) $N$-methylated cyclic pentaalanine peptides as template structures. J Am Chem Soc 128:15164-15172. https://doi.org/10.1021/ja063123d

Chatterjee J, Laufer B, Kessler H (2012) Synthesis of $N$ methylated cyclic peptides. Nat Protoc 7:432-444. https:// doi.org/10.1038/nprot.2011.450

Chen X, Si L, Liu D, Proksch P, Zhang L, Zhou D, Lin W (2015) Neoechinulin B and its analogues as potential entry inhibitors of influenza viruses, targeting viral hemagglutinin. Eur J Med Chem 93:182-195. https://doi.org/10.1016/j. ejmech.2015.02.006

Chen Z, Xu X, Ren J, Wang W, Liu X, Li E (2017) Trichopeptides $\mathrm{A}$ and $\mathrm{B}$, trichocyclodipeptides A-C, new peptides from the ascomycete fungus Stagonospora trichophoricola. J Antibiot (Tokyo) 70:923-928. https://doi. org/10.1038/ja.2017.76

Chu YS, Niu XM, Wang YL, Guo JP, Pan WZ, Huang XW, Zhang KQ (2010) Isolation of putative biosynthetic intermediates of prenylated indole alkaloids from a thermophilic fungus Talaromyces thermophilus. Org Lett 12:4356-4359. https://doi.org/10.1021/ol101817g

Chunyu WX, Ding ZG, Zhao JY, Wang YX, Han XL, Li MG, Wen ML (2017) Two new diketopiperazines from the tin mine tailings-derived fungus Schizophyllum commune YIM DT10058. Nat Prod Res 31:1566-1572. https://doi. org/10.1080/14786419.2016.1274894

Cruz LJ, Insua MM, Baz JP, Trujillo M, Rodriguez-Mias RA, Oliveira E, Giralt E, Albericio F, Cañedo LM (2006) IB01212, a new cytotoxic cyclodepsipeptide isolated from the marine fungus Clonostachys sp. ESNA-A009. J Org Chem 71:3335-3338. https://doi.org/10.1021/jo051600p

Cryle MJ, Bell SG, Schlichting I (2010) Structural and biochemical characterization of the cytochrome P450 CypX (CYP134A1) from Bacillus subtilis: a cyclo-L-leucyl-Lleucyl dipeptide oxidase. Biochemistry 49:7282-7296. https://doi.org/10.1021/bi100910y

Dewapriya P, Khalil ZG, Prasad P, Salim AA, Cruz-Morales P, Marcellin E, Capon RJ (2018) Talaropeptides A-D: structure and biosynthesis of extensively $\mathrm{N}$-methylated linear peptides from an Australian marine tunicate-derived Talaromyces sp. Front Chem 6:394. https://doi.org/10. 3389/fchem.2018.00394

Ding G, Jiang L, Guo L, Chen X, Zhang H, Che Y (2008) Pestalazines and pestalamides, bioactive metabolites from the plant pathogenic fungus Pestalotiopsis theae. J Nat Prod 71:1861-1865. https://doi.org/10.1021/np800357g

Dong JY, He HP, Shen YM, Zhang KQ (2005) Nematicidal epipolysulfanyldioxopiperazines from Gliocladium roseum. J Nat Prod 68:1510-1513. https://doi.org/10.1021/ np0502241

Dopstadt J, Neubauer L, Tudzynski P, Humpf HU (2016) The epipolythiodiketopiperazine gene cluster in Claviceps purpurea: dysfunctional cytochrome P450 enzyme prevents formation of the previously unknown Clapurines. PLoS ONE 11:e0158945. https://doi.org/10.1371/journal. pone. 0158945

Du FY, Li XM, Li CS, Shang Z, Wang BG (2012) Cristatumins A-D, new indole alkaloids from the marine-derived endophytic fungus Eurotium cristatum EN-220. Bioorg Med Chem Lett 22:4650-4653. https://doi.org/10.1016/j.bmcl. 2012.05.088

El-Gendy BD, Rateb ME (2015) Antibacterial activity of diketopiperazines isolated from a marine fungus using t-butoxycarbonyl group as a simple tool for purification. Bioorg Med Chem Lett 25:3125-3128. https://doi.org/10. 1016/j.bmcl.2015.06.010

Fujimoto H, Fujimaki T, Okuyama E, Yamazaki M (1999) Immunomodulatory constituents from an ascomycete, Microascus tardifaciens. Chem Pharm Bull (Tokyo) 47:1426-1432. https://doi.org/10.1248/cpb.47.1426

Fujimoto H, Sumino M, Okuyama E, Ishibashi M (2004) Immunomodulatory constituents from an ascomycete, Chaetomium seminudum. J Nat Prod 67:98-102. https:// doi.org/10.1021/np0302201

Fukuda T, Shinkai M, Sasaki E, Nagai K, Kurihara Y, Kanamoto A, Tomoda H (2015a) Graphiumins, new thiodiketopiperazines from the marine-derived fungus Graphium sp. OPMF00224. J Antibiot (Tokyo) 68:620-627. https:// doi.org/10.1038/ja.2015.41

Fukuda T, Nagai K, Kurihara Y, Kanamoto A, Tomod H (2015b) Graphiumins I and J, new thiodiketopiperazines from the marine-derived fungus Graphium sp. OPMF00224. Nat Prod Sci 21:255-260. https://doi.org/10. 20307/nps.2015.21.4.255

Furutani S, Nakatani Y, Miura Y, Ihara M, Kai K, Hayashi H, Matsuda K (2014) GluCl a target of indole alkaloid okaramines: a 25 year enigma solved. Sci Rep 4:6190. https://doi.org/10.1038/srep06190

García-Estrada C, Ullán RV, Albillos SM, Fernández-Bodega MÁ, Durek P, von Döhren H, Martín JF (2011) A single cluster of coregulated genes encodes the biosynthesis of the mycotoxins roquefortine $\mathrm{C}$ and meleagrin in Penicillium chrysogenum. Chem Biol 18:1499-1512. https://doi.org/ 10.1016/j.chembiol.2011.08.012

Gardiner DM, Howlett BJ (2005) Bioinformatic and expression analysis of the putative gliotoxin biosynthetic gene cluster of Aspergillus fumigatus. FEMS Microbiol Lett 248:241-248. https://doi.org/10.1016/j.femsle.2005.05. 046

Gardiner DM, Cozijnsen AJ, Wilson LM, Pedras MS, Howlett BJ (2004) The sirodesmin biosynthetic gene cluster of the plant pathogenic fungus Leptosphaeria maculans. Mol Microbiol 53:1307-1318. https://doi.org/10.1111/j.13652958.2004.04215.x

Garo E, Starks CM, Jensen PR, Fenical W, Lobkovsky E, Clardy J (2003) Trichodermamides A and B, cytotoxic modified dipeptides from the marine-derived fungus Trichoderma virens. J Nat Prod 66:423-426. https://doi.org/10.1021/ np0204390

Gerken T, Walsh CT (2013) Cloning and sequencing of the chaetocin biosynthetic gene cluster. ChemBioChem 14:2256-2258. https://doi.org/10.1002/cbic.201300513 
Giessen TW, von Tesmar AM, Marahiel MA (2013) Insights into the generation of structural diversity in a tRNA-dependent pathway for highly modified bioactive cyclic dipeptides. Chem Biol 20:828-838. https://doi.org/10. 1016/j.chembiol.2013.04.017

Gulder TA, Hong H, Correa J, Egereva E, Wiese J, Imhoff JF, Gross H (2012) Isolation, structure elucidation and total synthesis of lajollamide A from the marine fungus Asteromyces cruciatus. Mar Drugs 10:2912-2935. https://doi. org/10.3390/md10122912

Guo HJ, Sun BD, Gao H, Chen XL, Liu SC, Yao XS, Liu XZ, Che YS (2009) Diketopiperazines from the cordycepscolonizing fungus Epicoccum nigrum. J Nat Prod 72:2115-2119. https://doi.org/10.1021/np900654a

Guo CJ, Yeh HH, Chiang YM, Sanchez JF, Chang SL, Bruno KS, Wang CC (2013) Biosynthetic pathway for the epipolythiodioxopiperazine acetylaranotin in Aspergillus terreus revealed by genome-based deletion analysis. J Am Chem Soc 135:7205-7213. https://doi.org/10.1021/ ja3123653

Guo H, Kreuzenbeck NB, Otani S, Garcia-Altares M, Dahse HM, Weigel C, Aanen DK, Hertweck C, Poulsen M, Beemelmanns C (2016) Pseudoxylallemycins A-F, cyclic tetrapeptides with rare allenyl modifications isolated from Pseudoxylaria sp. X802: a competitor of fungus-growing termite cultivars. Org Lett 18:3338-3341. https://doi.org/ 10.1021/acs.orglett.6b01437

Guo H, Schmidt A, Stephan P, Raguž L, Braga D, Kaiser M, Dahse HM, Weigel C, Lackner G, Beemelmanns C (2018) Precursor-directed diversification of cyclic tetrapeptidic pseudoxylallemycins. ChemBioChem 19:2307-2311. https://doi.org/10.1002/cbic.201800503

Haritakun R, Rachtawee P, Komwijit S, Nithithanasilp S, Isaka M (2012) Highly conjugated ergostane-type steroids and aranotin-type diketopiperazines from the fungus Aspergillus terreus BCC 4651. Helv Chim Acta 95:308-313. https://doi.org/10.1002/hlca.201100335

Herath KB, Jayasuriya H, Ondeyka JG, Polishook JD, Bills GF, Dombrowski AW, Cabello A, Vicario PP, Zweerink H, Guan Z, Singh SB (2005) Isolation and structures of novel fungal metabolites as chemokine receptor (CCR46) antagonists. J Antibiot (Tokyo) 58:686-694. https://doi. org/10.1038/ja.2005.94

Herath HM, Jacob M, Wilson AD, Abbas HK, Nanayakkara NP (2013) New secondary metabolites from bioactive extracts of the fungus Armillaria tabescens. Nat Prod Res 27:1562-1568. https://doi.org/10.1080/14786419.2012. 738206

Huang S, Ding W, Li C, Cox DG (2014) Two new cyclopeptides from the co-culture broth of two marine mangrove fungi and their antifungal activity. Pharmacogn Mag 10:410-414. https://doi.org/10.4103/0973-1296.141781

Hwang IH, Che Y, Swenson DC, Gloer JB, Wicklow DT, Peterson SW, Dowd PF (2016) Haenamindole and fumiquinazoline analogs from a fungicolous isolate of Penicillium lanosum. J Antibiot (Tokyo) 69:631-636. https://doi.org/10.1038/ja.2016.74

Isaka M, Palasarn S, Rachtawee P, Vimuttipong S, Kongsaeree $P$ (2005) Unique diketopiperazine dimers from the insect pathogenic fungus Verticillium hemipterigenum BCC
1449. Org Lett 7:2257-2260. https://doi.org/10.1021/ ol0507266

Isaka M, Srisanoh U, Lartpornmatulee N, Boonruangprapa T (2007) ES-242 derivatives and cycloheptapeptides from Cordyceps sp. strains BCC 16173 and BCC 16176. J Nat Prod 70:1601-1604. https://doi.org/10.1021/np070357h

Ishikawa K, Hosoe T, Itabashi T, Wakana D, Takizawa K, Yaguchi T, Kawai K (2010) Novoamauromine and entcycloechinulin: two new diketopiperazine derivatives from Aspergillus novofumigatus. Chem Pharm Bull (Tokyo) 58:717-719. https://doi.org/10.1248/cpb.58.717

Jia Y, Shi H, Fan D (2015) Significance of gastrin-releasing peptide in ovarian cancer ES2 cells. Oncol Lett 10:359-363. https://doi.org/10.3892/ol.2015.3240

Kajula M, Ward JM, Turpeinen A, Tejesvi MV, Hokkanen J, Tolonen A, Häkkänen H, Picart P, Ihalainen J, Sahl HG, Pirttilä AM, Mattila S (2016) Bridged epipolythiodiketopiperazines from Penicillium raciborskii, an endophytic fungus of Rhododendron tomentosum Harmaja. J Nat Prod 79:685-690. https://doi.org/10.1021/np500822k

Kato N, Furutani S, Otaka J, Noguchi A, Kinugasa K, Kai K, Hayashi H, Ihara M, Takahashi S, Matsuda K, Osada H (2018) Biosynthesis and structure-activity relationship studies of okaramines that target insect glutamate-gated chloride channels. ACS Chem Biol 13:561-566. https:// doi.org/10.1021/acschembio.7b00878

Kim JW, Ko SK, Son S, Shin KS, Ryoo IJ, Hong YS, Oh H, Hwang BY, Hirota H, Takahashi S, Kim BY, Osada H, Jang JH, Ahn JS (2015) Haenamindole, an unusual diketopiperazine derivative from a marine-derived Penicillium sp. KCB12F005. Bioorg Med Chem Lett 25:5398-5401. https://doi.org/10.1016/j.bmcl.2015.09.026

Klausmeyer P, McCloud TG, Tucker KD, Cardellina JH II, Shoemaker RH (2005) Aspirochlorine class compounds from Aspergillus flavus inhibit azole-resistant Candida albicans. J Nat Prod 68:1300-1302. https://doi.org/10. 1021/np050141k

Kleinwächter P, Dahse HM, Luhmann U, Schlegel B, Dornberger K (2001) Epicorazine C, an antimicrobial metabolite from Stereum hirsutum HKI 0195. J Antibiot (Tokyo) 54:521-525. https://doi.org/10.7164/antibiotics.54.521

Kojima Y, Sunazuka T, Nagai K, Hirose T, Namatame M, Ishiyama A, Otoguro K, Omura S (2009) Solid-phase synthesis and biological activity of malformin $\mathrm{C}$ and its derivatives. J Antibiot (Tokyo) 62:681-686. https://doi. org/10.1038/ja.2009.100

Koolen HH, Soares ER, Silva FM, Souza AQ, Medeiros LS, Filho ER, Almeida RA, Ribeiro IA, Pessoa Cdo Ó, Morais MO, Costa PM, Souza AD (2012) An antimicrobial diketopiperazine alkaloid and co-metabolites from an endophytic strain of gliocladium isolated from Strychnos cf. toxifera. Nat Prod Res 26:2013-2019. https://doi.org/10. 1080/14786419.2011.639070

Koyama N, Kojima S, Fukuda T, Nagamitsu T, Yasuhara T, Omura S, Tomoda H (2010a) Structure and total synthesis of fungal calpinactam, a new antimycobacterial agent. Org Lett 12:432-435. https://doi.org/10.1021/o1902553z

Koyama N, Kojima S, Nonaka K, Masuma R, Matsumoto M, Omura S, Tomoda H (2010b) Calpinactam, a new antimycobacterial agent, produced by Mortierella alpina FKI- 
4905. J Antibiot (Tokyo) 63:183-186. https://doi.org/10. 1038/ja.2010.14

Kozlovsky AG, Adanin VM, Dahse HM, Grafe U (2001) Rugulosuvines A and B, diketopiperazine alkaloids of Penicillium rugulosum and Penicillium piscarium fungi. Appl Biochem Microbiol 37:253-256. https://doi.org/10. 1023/A: 1010225017054

Krasnoff SB, Keresztes I, Gillilan RE, Szebenyi DM, Donzelli BG, Churchill AC, Gibson DM (2007) Serinocyclins A and B, cyclic heptapeptides from Metarhizium anisopliae. J Nat Prod 70:1919-1924. https://doi.org/10.1021/np070407i

Kumar S, Dahiya R, Khokra SL, Mourya R, Chennupati SV, Maharaj S (2017) Total synthesis and pharmacological investigation of cordyheptapeptide A. Molecules 22:E682. https://doi.org/10.3390/molecules22060682

Kwon HJ, Kim JH, Kim M, Lee JK, Hwang WS, Kim DY (2003) Anti-parasitic activity of depudecin on Neospora caninum via the inhibition of histone deacetylase. Vet Parasitol 112:269-276. https://doi.org/10.1016/S0304-4017(03)000 35-9

Lautru S, Gondry M, Genet R, Pernodet JL (2002) The albonoursin gene cluster of $S$. noursei biosynthesis of diketopiperazine metabolites independent of nonribosomal peptide synthetases. Chem Biol 9:1355-1364. https://doi. org/10.1016/S1074-5521(02)00285-5

Lazos O, Tosin M, Slusarczyk AL, Boakes S, Cortés J, Sidebottom PJ, Leadlay PF (2010) Biosynthesis of the putative siderophore erythrochelin requires unprecedented crosstalk between separate nonribosomal peptide gene clusters. Chem Biol 17:160-173. https://doi.org/10.1016/j.chemb iol.2010.01.011

Li Y, Li X, Kang JS, Choi HD, Son BW (2004) New radical scavenging and ultraviolet-A protecting prenylated dioxopiperazine alkaloid related to isoechinulin A from a marine isolate of the fungus Aspergillus. J Antibiot (Tokyo) 57:337-340. https://doi.org/10.7164/antibiotics. 57.337

Li X, Kim SK, Nam KW, Kang JS, Choi HD, Son BW (2006) A new antibacterial dioxopiperazine alkaloid related to gliotoxin from a marine isolate of the fungus Pseudallescheria. J Antibiot (Tokyo) 59:248-250. https://doi. org/10.1038/ja.2006.35

Li L, Li D, Luan Y, Gu Q, Zhu T (2012a) Cytotoxic metabolites from the antarctic psychrophilic fungus Oidiodendron truncatum. J Nat Prod 75:920-927. https://doi.org/10. 1021/np3000443

Li XJ, Zhang Q, Zhang AL, Gao JM (2012b) Metabolites from Aspergillus fumigatus, an endophytic fungus associated with Melia azedarach, and their antifungal, antifeedant, and toxic activities. J Agric Food Chem 60:3424-3431. https://doi.org/10.1021/jf300146n

Li L, Zhu T, Li D, Gu Q (2013a) Progress in the research of epipolythiodioxopiperazines. Chin J Antibiot 38:161-174. https://doi.org/10.13461/j.cnki.cja.005146 In Chinese

Li Y, Sun KL, Wang Y, Fu P, Liu PP, Wang C, Zhu WM (2013b) A cytotoxic pyrrolidinoindoline diketopiperazine dimer from the algal fungus eurotium herbariorum HT-2. Chin Chem Lett 24:1049-1052. https://doi.org/10.1016/j.cclet. 2013.07.028

Li Y, Yue Q, Krausert NM, An Z, Gloer JB, Bills GF (2016a) Emestrins: anti-Cryptococcus epipolythiodioxopiperazines from Podospora australis. J Nat Prod 79:2357-2363. https:// doi.org/10.1021/acs.jnatprod.6b00498

Li G, Kusari S, Golz C, Strohmann C, Spiteller M (2016b) Three cyclic pentapeptides and a cyclic lipopeptide produced by endophytic Fusarium decemcellulare LG53. RSC Adv 6:54092-54098. https://doi.org/10.1039/C6RA10905E

Li YL, Guo H, Zhao YQ, Li AF, Ren YQ, Zhang JW (2017) Quercetin protects neuronal cells from oxidative stress and cognitive degradation induced by amyloid $\beta$-peptide treatment. Mol Med Rep 16:1573-1577. https://doi.org/10. 3892/mmr.2017.6704

Liermann JC, Opatz T, Kolshorn H, Antelo L, Hof C, Anke H (2009) Omphalotins E-I, five oxidatively modified nematicidal cyclopeptides from Omphalotus olearius. Eur J Org Chem 40:1256-1262. https://doi.org/10.1002/chin. 200925186

Lim FY, Ames B, Walsh CT, Keller NP (2014) Co-ordination between BrlA regulation and secretion of the oxidoreductase FmqD directs selective accumulation of fumiquinazoline $\mathrm{C}$ to conidial tissues in Aspergillus fumigatus. Cell Microbiol 16:1267-1283. https://doi.org/10.1111/cmi. 12284

Liu Y, Li XM, Meng LH, Jiang WL, Xu GM, Huang CG, Wang BG (2015a) Bisthiodiketopiperazines and acorane sesquiterpenes produced by the marine-derived fungus Penicillium adametzioides AS-53 on different culture media. J Nat Prod 78:1294-1299. https://doi.org/10.1021/ acs.jnatprod.5b00102

Liu Y, Mándi A, Li XM, Meng LH, Kurtán T, Wang BG (2015b) Peniciadametizine A, a dithiodiketopiperazine with a unique spiro[furan-2,7'-pyrazino[1,2-b][1,2]oxazine] skeleton, and a related analogue, peniciadametizine $\mathrm{B}$, from the marine sponge-derived fungus Penicillium adametzioides. Mar Drugs 13:3640-3652. https://doi.org/10.3390/md13063640

Luo X, Zhou X, Lin X, Qin X, Zhang T, Wang J, Tu Z, Yang B, Liao S, Tian Y, Pang X, Kaliyaperumal K, Li JL, Tao H, Liu Y (2017) Antituberculosis compounds from a deep-seaderived fungus Aspergillus sp. SCSIO Ind09F01. Nat Prod Res 31:1958-1962. https://doi.org/10.1080/14786419.2016. 1266353

Luque-Ortega JR, Cruz LJ, Albericio F, Rivas L (2010) The antitumoral depsipeptide IB-01212 kills Leishmania through an apoptosis-like process involving intracellular targets. Mol Pharm 7:1608-1617. https://doi.org/10.1021/ mp100035f

Ma YM, Liang XA, Zhang HC, Liu R (2016) Cytotoxic and antibiotic cyclic pentapeptide from an endophytic Aspergillus tamarii of Ficus carica. J Agric Food Chem 64:3789-3793. https://doi.org/10.1021/acs.jafc.6b01051

Ma X, Nong XH, Ren Z, Wang J, Liang X, Wang L, Qi SH (2017) Antiviral peptides from marine gorgonian-derived fungus Aspergillus sp. SCSIO 41501. Tetrahedron Lett 58:1151-1155. https://doi.org/10.1016/j.tetlet.2017.02. 005

Maiya S, Grundmann A, Li SM, Turner G (2006) The fumitremorgin gene cluster of Aspergillus fumigatus: identification of a gene encoding brevianamide $\mathrm{F}$ synthetase. ChemBioChem 7:1062-1069. https://doi.org/10.1002/cbic. 200600003

Maiya S, Grundmann A, Li SM, Turner G (2009) Improved tryprostatin $\mathrm{B}$ production by heterologous gene expression 
in Aspergillus nidulans. Fungal Genet Biol 46:436-440. https://doi.org/10.1016/j.fgb.2009.01.003

Meng LH, Zhang P, Li XM, Wang BG (2015a) Penicibrocazines A-E, five new sulfide diketopiperazines from the marinederived endophytic fungus Penicillium brocae. Mar Drugs 13:276-287. https://doi.org/10.3390/md13010276

Meng LH, Du FY, Li XM, Pedpradab P, Xu GM, Wang BG (2015b) Rubrumazines A-C, indolediketopiperazines of the isoechinulin class from Eurotium rubrum MA-150, a fungus obtained from marine mangrove-derived rhizospheric soil. J Nat Prod 78:909-913. https://doi.org/10. 1021/np5007839

Meng LH, Wang CY, Mándi A, Li XM, Hu XY, Kassack MU, Kurtán T, Wang BG (2016) Three diketopiperazine alkaloids with spirocyclic skeletons and one bisthiodiketopiperazine derivative from the mangrove-derived endophytic fungus Penicillium brocae MA-231. Org Lett 18:5304-5307. https:// doi.org/10.1021/acs.orglett.6b02620

Metwaly AM, Ghoneim MM, Musa A (2015) Two new antileishmanial diketopiperazine alkaloids from the endophytic fungus Trichosporum sp. Der Pharma Chemica 7:322-327

Mundt K, Wollinsky B, Ruan HL, Zhu T, Li SM (2012) Identification of the verruculogen prenyltransferase FtmPT3 by a combination of chemical, bioinformatic and biochemical approaches. ChemBioChem 13:2583-2592. https://doi. org/10.1002/cbic.201200523

Nagai K, Koyama N, Sato N, Yanagisawa C, Tomoda H (2012) Synthesis and antimycobacterial activity of calpinactam derivatives. Bioorg Med Chem Lett 22:7739-7741. https:// doi.org/10.1016/j.bmcl.2012.09.069

Nilanonta C, Isaka M, Kittakoop P, Saenboonrueng J, Rukachaisirikul V, Kongsaeree P, Thebtaranonth Y (2003) New diketopiperazines from the entomopathogenic fungus Verticillium hemipterigenum BCC 1449. J Antibiot (Tokyo) 56:647-651. https://doi.org/10.7164/antibiotics. 56.647

Niu S, Liu D, Shao Z, Proksch P, Lin W (2017a) Eutypellazines $\mathrm{N}-\mathrm{S}$, new thiodiketopiperazines from a deep sea sediment derived fungus Eutypella sp. with anti-VRE activities. Tetrahedron Lett 58:3695-3699. https://doi.org/10.1016/j. tetlet.2017.08.015

Niu S, Liu D, Shao Z, Prokschc P, Lin W (2017b) Eutypellazines A-M, thiodiketopiperazine-type alkaloids from deep sea derived fungus Eutypella sp. MCCC 3A00281. RSC Adv 7:33580-33590. https://doi.org/10.1039/C7ra05774a

Ohyama T, Kurihara Y, Ono Y, Ishikawa T, Miyakoshi S, Hamano K, Arai M, Suzuki T, Igari H, Suzuki Y, Inukai M (2000) Arborcandins A, B, C, D, E and F, novel 1,3-betaglucan synthase inhibitors: production and biological activity. J Antibiot (Tokyo) 53:1108-1116. https://doi.org/ 10.7164/antibiotics.53.1108

Ohyama T, Iwadate-Kurihara Y, Ishikawa T, Miyakoshi S, Hamano K, Inukai M (2003) Arborcandins A, B, C, D, E and $\mathrm{F}$, novel 1,3-beta-glucan synthase inhibitors: physicochemical properties and structure elucidation. J Antibiot (Tokyo) 56:1024-1032. https://doi.org/10.7164/antibio tics.56.1024

Ohyama T, Miyakoshi S, Isono F (2004) FKS1 mutations responsible for selective resistance of Saccharomyces cerevisiae to the novel 1,3-beta-glucan synthase inhibitor arborcandin C. Antimicrob Agents Chemother 48:319322. https://doi.org/10.1128/AAC.48.1.319-322.2004

Oide S, Moeder W, Krasnoff S, Gibson D, Haas H, Yoshioka K, Turgeon BG (2006) NPS6, encoding a nonribosomal peptide synthetase involved in siderophore-mediated iron metabolism, is a conserved virulence determinant of plant pathogenic ascomycetes. Plant Cell 18:2836-2853. https:// doi.org/10.1105/tpc.106.045633

Onodera H, Hasegawa A, Tsumagari N, Nakai R, Ogawa T, Kanda Y (2004) MPC1001 and its analogues: new antitumor agents from the fungus Cladorrhinum species. Org Lett 6:4101-4104. https://doi.org/10.1021/ol048202d

Park HB, Kwon HC, Lee CH, Yang HO (2009) Glionitrin A, an antibiotic-antitumor metabolite derived from competitive interaction between abandoned mine microbes. J Nat Prod 72:248-252. https://doi.org/10.1021/np800606e

Pereira-Neves A, Menna-Barreto RF, Benchimol M (2016) The fungal metabolite gliotoxin inhibits proteasome proteolytic activity and induces an irreversible pseudocystic transformation and cell death in Tritrichomonas foetus. Parasitol Res 115:3057-3069. https://doi.org/10.1007/s00436-0165061-y

Quezada M, Shang Z, Kalansuriya P, Salim AA, Lacey E, Capon RJ (2017) Waspergillamide A, a Nitro depsi-tetrapeptide diketopiperazine from an Australian mud dauber wasp-associated Aspergillus sp. (CMB-W031). J Nat Prod 80:1192-1195. https://doi.org/10.1021/acs.jnatprod.6b01062

Räder AFB, Reichart F, Weinmüller M, Kessler H (2018) Improving oral bioavailability of cyclic peptides by $\mathrm{N}$ methylation. Bioorg Med Chem 26:2766-2773. https://doi. org/10.1016/j.bmc.2017.08.031

Rukachaisirikul V, Chantaruk S, Tansakul C, Saithong S, Chaicharernwimonkoon L, Pakawatchai C, Isaka M, Intereya K (2006) A cyclopeptide from the Insect pathogenic fungus Cordyceps sp. BCC 1788. J Nat Prod 69:305-307. https://doi.org/10.1021/np0504331

Saruwatari T, Yagishita F, Mino T, Noguchi H, Hotta K, Watanabe K (2014) Cytochrome P450 as dimerization catalyst in diketopiperazine alkaloid biosynthesis. ChemBioChem 15:656-659. https://doi.org/10.1002/cbic.201 300751

Seephonkai P, Kongsaeree P, Prabpai S, Isaka M, Thebtaranonth Y (2006) Transformation of an irregularly bridged epidithiodiketopiperazine to trichodermamide A. Org Lett 8:3073-3075. https://doi.org/10.1021/ol0610461

Sherkhane PD, Bansal R, Banerjee K, Chatterjee S, Oulkar D, Jain P, Rosenfelder L, Elgavish S, Horwitz BA, Mukherjee PK (2017) Genomics-driven discovery of the gliovirin biosynthesis gene cluster in the plant beneficial fungus Trichoderma Virens. ChemistrySelect 2:3347-3352. https://doi.org/10.1002/slct.201700262

Shiono Y, Akiyama K, Hayashi H (2000) Okaramines N, O, P, Q and $\mathrm{R}$, new okaramine congeners, from Penicillium simplicissimum ATCC 90288. Biosci Biotechnol Biochem 64:103-110. https://doi.org/10.1271/bbb.64.103

Singh SB, Zink DL, Liesch JM, Dombrowski AW, DarkinRattray SJ, Schmatz DM, Goetz MA (2001) Structure, histone deacetylase, and antiprotozoal activities of apicidins $\mathrm{B}$ and $\mathrm{C}$, congeners of apicidin with proline and valine substitutions. Org Lett 3:2815-2818. https://doi.org/ 10.1021/o1016240g 
Singh SB, Zink DL, Liesch JM, Mosley RT, Dombrowski AW, Bills GF, Darkin-Rattray SJ, Schmatz DM, Goetz MA (2002) Structure and chemistry of apicidins, a class of novel cyclic tetrapeptides without a terminal alpha-keto epoxide as inhibitors of histone deacetylase with potent antiprotozoal activities. J Org Chem 67:815-825. https:// doi.org/10.1021/jo016088w

Song F, Liu X, Guo H, Ren B, Chen C, Piggott AM, Yu K, Gao H, Wang Q, Liu M, Liu X, Dai H, Zhang L, Capon RJ (2012) Brevianamides with antitubercular potential from a marine-derived isolate of Aspergillus versicolor. Org Lett 14:4770-4773. https://doi.org/10.1021/ol302051x

Sugawara F (1990) Structure of malformin $A_{2}$, reinvestigation of phytotoxic metabolites produced by Aspergillus niger. Tetrahedron Lett 31:4337-4340. https://doi.org/10.1016/ S0040-4039(00)97615-9

Survase SA, Kagliwal LD, Annapure US, Singhal PS (2011) Cyclosporin A-A review on fermentative production, downstream processing and pharmacological applications. Biotechnol Adv 29:418-435. https://doi.org/10.1016/j. biotechadv.2011.03.004

Suzuki Y, Takahashi H, Esumi Y, Arie T, Morita T, Koshino H, Uzawa J, Uramoto M, Yamaguchi I (2000) Haematocin, a new antifungal diketopiperazine produced by Nectria haematococca Berk. et Br. (880701a-1) causing nectria blight disease on ornamental plants. J Antibiot (Tokyo) 53:45-49. https://doi.org/10.7164/antibiotics.53.45

Talontsi FM, Facey P, Tatong MD, Tofazzal Islam M, Frauendorf H, Draeger S, Av Tiedemann, Laatsch H (2012) Zoosporicidal metabolites from an endophytic fungus Cryptosporiopsis sp. of Zanthoxylum leprieurii. Phytochemistry 83:87-94. https://doi.org/10.1016/j.phytochem. 2012.06.006

Tan QW, Gao FL, Wang FR, Chen QJ (2015) Anti-TMV activity of malformin A1, a cyclic penta-peptide produced by an endophytic fungus Aspergillus tubingensis FJBJ11. Int J Mol Sci 16:5750-5761. https://doi.org/10.3390/ ijms 16035750

Tsumagari N, Nakai R, Onodera H, Hasegawa A, Rahayu ES, Ando K, Yamashita Y (2004) MPC1001, a new antitumor antibiotic produced by Cladorrhinum sp. J Antibiot (Tokyo) 57:532-534. https://doi.org/10.7164/antibiotics. 57.532

van der Velden NS, Kälin N, Helf MJ, Piel J, Freeman MF, Künzler M (2017) Autocatalytic backbone $N$-methylation in a family of ribosomal peptide natural products. Nat Chem Biol 13:833-835. https://doi.org/10.1038/nchembio. 2393

Varoglu M, Crews P (2000) Biosynthetically diverse compounds from a saltwater culture of sponge-derived Aspergillus niger. J Nat Prod 63:41-43. https://doi.org/10.1021/ np9902892

Vior NM, Lacret R, Chandra G, Dorai-Raj S, Trick M, Truman AW (2018) Discovery and biosynthesis of the antibiotic bicyclomycin in distantly related bacterial classes. Appl Environ Microbiol 84:e02828-17. https://doi.org/10.1128/ AEM.02828-17

von Bargen KW, Niehaus EM, Bergander K, Brun R, Tudzynski B, Humpf HU (2013) Structure elucidation and antimalarial activity of apicidin F: an apicidin-like compound produced by Fusarium fujikuroi. J Nat Prod 76:2136-2140. https://doi.org/10.1021/np4006053

Wang W, Wang Y, Tao H, Peng X, Liu P, Zhu W (2009) Cerebrosides of the halotolerant fungus Alternaria raphani isolated from a sea salt field. J Nat Prod 72:1695-1698. https://doi.org/10.1021/np9002299

Wang X, You J, King JB, Powell DR, Cichewicz RH (2012) Waikialoid A suppresses hyphal morphogenesis and inhibits biofilm development in pathogenic Candida albicans. J Nat Prod 75:707-715. https://doi.org/10.1021/ np2009994

Wang Y, Wang P, Ma H, Zhu W (2013a) Developments around the bioactive diketopiperazines: a patent review. Expert Opin Ther Pat 23:1415-1433. https://doi.org/10.1517/ 13543776.2013.828036

Wang MH, Li XM, Li CS, Ji NY, Wang BG (2013b) Secondary metabolites from Penicillium pinophilum SD-272, a marine sediment-derived fungus. Mar Drugs 11:2230-2238. https://doi.org/10.3390/md11062230

Wang X, Li Y, Zhang X, Lai D, Zhou L (2017a) Structural diversity and biological activities of the cyclodipeptides from fungi. Molecules 22:E2026. https://doi.org/10.3390/ molecules 22122026

Wang X, Lin M, Xu D, Lai D, Zhou L (2017b) Structural diversity and biological activities of fungal cyclic peptides, excluding cyclodipeptides. Molecules 22:E2069. https:// doi.org/10.3390/molecules22122069

Wang Y, Hu P, Pan Y, Zhu Y, Liu X, Che Y, Liu G (2017c) Identification and characterization of the verticillin biosynthetic gene cluster in Clonostachys rogersoniana. Fungal Genet Biol 103:25-33. https://doi.org/10.1016/j. fgb.2017.03.007

Watts KR, Ratnam J, Ang KH, Tenney K, Compton JE, McKerrow J, Crews P (2010) Assessing the trypanocidal potential of natural and semi-synthetic diketopiperazines from two deep water marine-derived fungi. Bioorg Med Chem 18:2566-2574. https://doi.org/10.1016/j.bmc.2010. 02.034

Wei W, Jiang N, Mei YN, Chu YL, Ge HM, Song YC, Ng SW, Tan RX (2014) An antibacterial metabolite from Lasiodiplodia pseudotheobromae F2. Phytochemistry 100:103-109. https://doi.org/10.1016/j.phytochem.2014. 01.003

Wilhite SE, Lumsden RD, Straney DC (2001) Peptide synthetase gene in Trichoderma virens. Appl Environ Microbiol 67:5055-5062. https://doi.org/10.1128/AEM.67.11. 5055-5062.2001

Wohlgemuth V, Kindinger F, Xie X, Wang BG, Li SM (2017) Two prenyltransferases govern a consecutive prenylation cascade in the biosynthesis of echinulin and neoechinulin. Org Lett 19:5928-5931. https://doi.org/10.1021/acs. orglett. $7 \mathrm{~b} 02926$

Wohlgemuth V, Kindinger F, Li SM (2018) Convenient synthetic approach for tri- and tetraprenylated cyclodipeptides by consecutive enzymatic prenylations. Appl Microbiol Biotechnol 102:2671-2681. https://doi.org/10.1007/ s00253-018-8761-7

Wu W, Dai H, Bao L, Ren B, Lu J, Luo Y, Guo L, Zhang L, Liu $\mathrm{H}$ (2011) Isolation and structural elucidation of prolinecontaining cyclopentapeptides from an endolichenic 
Xylaria sp. J Nat Prod 74:1303-1308. https://doi.org/10. 1021/np100909y

Xu GB, He G, Bai HH, Yang T, Zhang GL, Wu LW, Li GY (2015) Indole Alkaloids from Chaetomium globosum. J Nat Prod 78:1479-1485. https://doi.org/10.1021/np5007235

Xu WF, Hou XM, Yao FH, Zheng N, Li J, Wang CY, Yang RY, Shao CL (2017) Xylapeptide A, an antibacterial cyclopentapeptide with an uncommon L-pipecolinic acid moiety from the associated fungus Xylaria sp. (GDG-102). Sci Rep 7:6937. https://doi.org/10.1038/s41598-01707331-4

Yagi A, Uchida R, Hamamoto H, Sekimizu K, Kimura KI, Tomoda H (2017) Anti-mycobacterium activity of microbial peptides in a silkworm infection model with $M y$ cobacterium smegmatis. J Antibiot (Tokyo) 70:685-690. https://doi.org/10.1038/ja.2017.23

Yao T, Liu J, Liu Z, Li T, Li H, Che Q, Zhu T, Li D, Gu Q, Li W (2018) Genome mining of cyclodipeptide synthases unravels unusual tRNA-dependent diketopiperazine-terpene biosynthetic machinery. Nat Commun 9:4091. https:// doi.org/10.1038/s41467-018-06411-x

Yin WB, Grundmann A, Cheng J, Li SM (2009) Acetylaszonalenin biosynthesis in Neosartorya fischeri. Identification of the biosynthetic gene cluster by genomic mining and functional proof of the genes by biochemical investigation. J Biol Chem 284:100-109. https://doi.org/10.1074/ jbc.M807606200

Youssef DT, Alahdal AM (2018) Cytotoxic and antimicrobial compounds from the marine-derived fungus, Penicillium species. Molecules 23:E394. https://doi.org/10.3390/ molecules 23020394

Yu HC, Lee HJ, Jin ZW, Hwang SE, Yang JD, Lim HS, Yang YH, Murakami G, Cho BH (2012) Computer-assisted three-dimensional reconstruction of the fetal pancreas including the supplying arteries according to immunohistochemistry of pancreatic polypeptide. Surg Radiol Anat 234:229-233. https://doi.org/10.1007/s00276-011-0844-4

Yu G, Zhou G, Zhu M, Wang W, Zhu T, Gu Q, Li D (2016) Neosartoryadins A and B, fumiquinazoline alkaloids from a mangrove-derived fungus Neosartorya udagawae HDN13-313. Org Lett 18:244-247. https://doi.org/10. 1021/acs.orglett.5b02964

Yu FX, Chen Y, Yang YH, Li GH, Zhao PJ (2018) A new epipolythiodioxopiperazine with antibacterial and cytotoxic activities from the endophytic fungus Chaetomium sp. M336. Nat Prod Res 32:689-694. https://doi.org/10. 1080/14786419.2017.1338285

Zhang Y, Liu S, Che Y, Liu X (2007a) Epicoccins A-D, epipolythiodioxopiperazines from a Cordyceps-colonizing isolate of Epicoccum nigrum. J Nat Prod 70:1522-1525. https://doi.org/10.1021/np070239u
Zhang D, Noviendri D, Nursid M, Yang X, So BW (2007b) 12,13-Dihydroxyfumitremorgin $\mathrm{C}$, fumitremorgin $\mathrm{C}$, and brevianamide $\mathrm{F}$, antibacterial diketopiperazine alkaloids from the marine-derived fungus Pseudallescheria sp. Nat Prod Sci 13:251-254

Zhang M, Wang WL, Fang YC, Zhu TJ, Gu QQ, Zhu WM (2008) Cytotoxic alkaloids and antibiotic nordammarane triterpenoids from the marine-derived fungus Aspergillus sydowi. J Nat Prod 71:985-989. https://doi.org/10.1021/ np700737g

Zhang Q, Li S, Chen Y, Tian X, Zhang H, Zhang G, Zhu Y, Zhang S, Zhang W, Zhang C (2013) New diketopiperazine derivatives from a deep-sea-derived Nocardiopsis alba SCSIO 03039. J Antibiot (Tokyo) 66:31-36. https://doi. org/10.1038/ja.2012.88

Zheng CJ, Kim CJ, Bae KS, Kim YH, Kim WG (2006) Bionectins A-C, epidithiodioxopiperazines with anti-MRSA activity, from Bionectra byssicola F120. J Nat Prod 69:1816-1819. https://doi.org/10.1021/np060348t

Zheng CJ, Park SH, Koshino H, Kim YH, Kim WG (2007a) Verticillin G, a new antibacterial compound from Bionectra byssicola. J Antibiot (Tokyo) 60:61-64. https:// doi.org/10.1038/ja.2007.8

Zheng CJ, Kim YH, Kim WG (2007b) Glioperazine B, as a new antimicrobial agent against Staphylococcus aureus, and glioperazine C: two new dioxopiperazines from Bionectra byssicola. Biosci Biotechnol Biochem 71:1979-1983. https://doi.org/10.1271/bbb.70167

Zhou Y, Debbab A, Wray V, Lin WH, Schulz B, Trepos R, Pile C, Hellio C, Proksch P, Aly AH (2014) Marine bacterial inhibitors from the sponge-derived fungus Aspergillus sp. Tetrahedron Lett 55:2789-2792. https://doi.org/10.1016/j. tetlet.2014.02.062

Zhou X, Fang W, Tan S, Lin X, Xun T, Yang B, Liu S, Liu Y (2016) Aspernigrins with anti-HIV-1 activities from the marine-derived fungus Aspergillus niger SCSIO Jcsw6F30. Bioorg Med Chem Lett 26:361-365. https://doi. org/10.1016/j.bmcl.2015.12.005

Zhu X, Zhong Y, Xie Z, Wu M, Hu Z, Ding W, Li C (2018) Fusarihexins A and B: novel cyclic hexadepsipeptides from the mangrove endophytic fungus Fusarium sp. R5 with antifungal activities. Planta Med 84:1355-1362. https:// doi.org/10.1055/a-0647-7048

Zou X, Niu S, Ren J, Li E, Liu X, Che Y (2011) Verrucamides A-D, antibacterial cyclopeptides from Myrothecium verrucaria. J Nat Prod 74:1111-1116. https://doi.org/10.1021/ np200050r

Publisher's Note Springer Nature remains neutral with regard to jurisdictional claims in published maps and institutional affiliations. 